\title{
LABOR MARKET REGULATIONS IN THE CONTEXT OF STRUCTURAL TRANSFORMATION
}

Priya Ranjan, Rana Hasan, and Erik Jan Eleazar

NO. 543

April 2018
ADB ECONOMICS WORKING PAPER SERIES 


\section{Labor Market Regulations in the Context of Structural Transformation}

Priya Ranjan, Rana Hasan, and Erik Jan Eleazar

No. 543 | April 2018
Priya Ranjan (pranjan@uci-edu) is a professor at the University of California, Irvine; Rana Hasan (rhasan@adb.org) is a director; and Erik Jan Eleazar (eeleazar.consultant@adb.org) is a consultant at the Economic Research and Regional Cooperation Department of the Asian Development Bank

We would like to thank the seminar participants at LSU, ISI Delhi, Jadavpur University, and the participants at the Asian Development Bank Conference on "Future of Jobs in Asia," held in Manila in 2016, for valuable comments. 
(C) 2018 Asian Development Bank

6 ADB Avenue, Mandaluyong City, 1550 Metro Manila, Philippines

Tel +632632 4444; Fax +6326362444

www.adb.org

Some rights reserved. Published in 2018.

ISSN 2313-6537 (print), 2313-6545 (electronic)

Publication Stock No. WPS189312-2

DOI: http://dx.doi.org/10.22617/WPS189312-2

The views expressed in this publication are those of the authors and do not necessarily reflect the views and policies of the Asian Development Bank (ADB) or its Board of Governors or the governments they represent.

ADB does not guarantee the accuracy of the data included in this publication and accepts no responsibility for any consequence of their use. The mention of specific companies or products of manufacturers does not imply that they are endorsed or recommended by ADB in preference to others of a similar nature that are not mentioned.

By making any designation of or reference to a particular territory or geographic area, or by using the term "country" in this document, $A D B$ does not intend to make any judgments as to the legal or other status of any territory or area.

This work is available under the Creative Commons Attribution 3.0 IGO license (CC BY 3.0 IGO)

https://creativecommons.org/licenses/by/3.0/igo/. By using the content of this publication, you agree to be bound by the terms of this license. For attribution, translations, adaptations, and permissions, please read the provisions and terms of use at https://www.adb.org/terms-use\#openaccess.

This CC license does not apply to non-ADB copyright materials in this publication. If the material is attributed to another source, please contact the copyright owner or publisher of that source for permission to reproduce it. $\mathrm{ADB}$ cannot be held liable for any claims that arise as a result of your use of the material.

Please contact pubsmarketing@adb.org if you have questions or comments with respect to content, or if you wish to obtain copyright permission for your intended use that does not fall within these terms, or for permission to use the ADB logo.

Notes:

In this publication, “\$” refers to United States dollars.

Corrigenda to ADB publications may be found at http://www.adb.org/publications/corrigenda. 


\section{CONTENTS}

TABLES AND FIGURES

I. INTRODUCTION 1

II. RELATED LITERATURE 3

$\begin{array}{ll}\text { III. THEMODEL } & 5\end{array}$

$\begin{array}{lr}\text { IV. } & \text { PLANNER'S PROBLEM }\end{array}$

V. LABOR MARKET REGULATIONS

A. Severance Payments/Unemployment Insurance $\quad 12$

B. Noncompliance, State Capacity, etc. 14

C. Administrative Burden of Firing $\quad 15$

D. Increase in General Regulatory Burden 18

E. Minimum Wage Regulation 20

VI. EMPIRICAL EXERCISE

A. Data and Variables $\quad 23$

$\begin{array}{ll}\text { B. } & \text { Results } \\ \end{array}$

VII. CONCLUDING REMARKS

$\begin{array}{ll}\text { APPENDIX } & 33\end{array}$

$\begin{array}{ll}\text { REFERENCES } & 41\end{array}$ 


\section{TABLES AND FIGURES}

\section{TABLES}

$1 \quad$ Summary Statistics $\quad 26$

2 Regression Results, Dismissal Regulations 29

3 Regression Results, Redundancy Compensation $\quad 30$

$4 \quad$ Regression Results, Minimum Wage to GDP Ratio 31

\section{FIGURES}

$1 \quad$ Risk Aversion and Labor Market Outcomes 11

$2 \quad$ Severance Payments and Labor Market Outcomes 13

3 Administrative Burden of Firing and Labor Market Outcomes 16

4 Regulatory Burden and Labor Market Outcomes 19

$5 \quad$ Minimum Wage and Labor Market Outcomes $\quad 22$

6 Scatter Plots: Share of Informal Employment 27 


\begin{abstract}
This paper constructs a theoretical model to study labor market regulations in developing countries within the context of structural transformation. When workers are risk averse and the market for insurance against labor income risk is missing, regulations that provide insurance to workers (such as severance payments) are efficiency enhancing and promote structural transformation. However, regulations that simply create barriers to the dismissal of workers not only impede structural transformation, they also end up reducing the welfare of workers. The implications of some other issues like general regulatory burden, weak state capacity, and minimum wage regulations are analyzed as well. The paper provides some empirical evidence broadly consistent with the theoretical results using cross-country data. While dismissal regulations increase the share of informal employment, severance payments to workers do not.
\end{abstract}

Key words: dismissal regulations, informal employment, minimum wage, severance payments, structural transformation

JEL codes: J38, J46, O12, O17, O57 


\section{INTRODUCTION}

Structural transformation is an integral process of economic development whereby resources move from less productive activities to more productive activities. This can happen through intersectoral reallocation of resources in which case resources move from say, less productive agriculture to more productive manufacturing. Alternatively, structural transformation can also take place through intrasectoral reallocation of resources. An example of the latter would be a decrease in the share of informal/unorganized manufacturing and increase in the share of formal/organized manufacturing. In this paper's theoretical model we focus on the latter aspect of structural transformation. The literature on informality identifies two key causes of it. One has to do with the motive of evading taxation. That is, by remaining informal, firms can avoid taxation. The other explanation is in terms of excessive regulation and labor market rigidities. The idea is that the regulation of labor markets in developing countries can have elements, such as restrictions on firing or high minimum wages, that induce firms to avoid meeting these regulations by remaining informal/unregistered. Again, this paper focuses on the latter without denying the importance of the former.

Governments in developing countries attempt to regulate labor markets along a number of dimensions such as wages, hours of work, hiring and firing restrictions, and conditions of work. When analyzing the desirability of any regulation, including those in the labor market, a natural question to ask is if the benefits of these regulations exceed the cost. This immediately suggests the need to develop a framework which will allow us to analyze the optimality of different labor market regulations. The standard framework to study labor market regulations in developed countries is a one-sector model that analyzes how a regulation affects the demand and supply for labor, and consequently the aggregate output (e.g., Summers 1989). This may not be appropriate in a developing country context, however. An important feature of developing countries is that a large fraction of the workforce is employed in informal/unorganized firms and as mentioned earlier, it is commonly believed that the excessive regulation of labor markets is one of the key factors responsible, preventing resources from moving to more productive formal firms. ${ }^{1}$ The aim of this paper is to provide an analytical framework to analyze labor market regulations in developing countries and study how they affect the intrasectoral allocation of resources between informal and formal firms. In addition, it also provides some suggestive empirical evidence broadly consistent with the theoretical results.

In most theoretical works dealing with labor market policies, to be discussed later, workers are assumed to be risk neutral, in which case there is no role for social protection. Policies such as employment protection or unemployment insurance are then viewed as distortionary by either raising the cost for employers or reducing the job search incentives for workers. Such models clearly understate the benefits of labor market regulations because if workers are risk neutral there is no need to insure them against labor market risk through social protection. Therefore, we construct a theoretical framework with two key features: risk-averse workers and the existence of an informal/unorganized sector. These two features allow us to study labor market regulations in a developing country context. Another feature of our model is job destruction by firms. This allows us to study labor market policies relating to firing of workers.

National Commission on Employment in the Unorganized Sector found that in 2004-2005, out of a total employment of 455.7 million workers in the Indian economy, 393.3 million were in the informal sector (Kanbur 2017). According to Ghani, Kerr, and O'Connell (2013), the employment share of the unorganized sector in Indian manufacturing has remained at around $81 \%$ between 1989 and 2005. 
In our model, there is a mass of entrepreneurs with heterogeneous entrepreneurial ability who can set up a firm in the informal sector using a simple technology with diminishing returns. Alternatively, they can set up a firm with a more sophisticated technology in the formal sector. There is a mass of risk averse but homogeneous workers who can work in either sector. While workers have identical productivities in the informal sector, the productivity in the formal sector is match specific. Firms in the formal sector commit to a level of wage in advance (similar to the competitive search literature) and hence fire workers with very low match-specific productivity. This is a way to capture endogenous job destruction in a static model and is similar in spirit to the framework of Blanchard and Tirole (2008). Workers who are fired in the formal sector get utility from home production/leisure. In equilibrium, workers are indifferent between working in the formal sector with a risk of unemployment or in the informal sector with a guaranteed but low-paying job. Therefore, wages are necessarily higher in the formal sector.

To see the role played by risk aversion in driving the results, we first derive results for the benchmark case of risk-neutral workers. It is shown that if workers are risk neutral then the decentralized outcome is production efficient. However, when risk-averse workers face the risk of unemployment in the formal sector and markets for insurance against labor income risk are missing, the decentralized outcome is not efficient. Moreover, employment in the formal sector and aggregate output both are decreasing in the risk aversion of workers.

Introducing policies that provide insurance to risk-averse workers is efficiency enhancing. It is shown that if the government can mandate severance payments to fired workers, both the aggregate output and the amount of labor employed in the formal sector increase. Alternatively, an unemployment insurance program funded by a layoff tax achieves the same outcome. While the two are equivalent theoretically, one or the other may be superior in practice. Mandated severance payments may suffer from noncompliance, either willful or because of the inability of a firm to pay it during crises. In this case, an unemployment insurance funded by a layoff tax may be preferable. The United States (US) unemployment insurance program with experience-rated contribution has this feature. The downside of state-provided unemployment insurance is that it may run into weak state capacity. In an extension, we capture weak state capacity by assuming that when government collects money from firms, only a fraction is given back to workers as benefits. The remaining fraction is lost due to corruption, mismanagement, etc. Clearly, leakage makes the policy ineffective and if the leakage is sufficiently high, no unemployment insurance may be better than poorly provided government unemployment insurance.

Since workers are facing a risk of unemployment, one may be tempted to conclude that a policy that reduces job destruction in the formal sector would be welfare improving. Employment protection policies that make it difficult for firms to fire workers would be one such policy. It turns out that such policies are counter productive. While they reduce firing by firms in the formal sector, they end up worsening the existing distortion and reduce aggregate output. Therefore, while the provision of unemployment insurance can aid the process of structural transformation, firing restrictions that create administrative hurdles for firing impede the process of structural transformation.

It is also shown that an increase in regulatory burden that makes it costly for firms to enter the formal sector reduces the size of the formal sector in addition to reducing aggregate output. Finally, the model is extended to study the implications of minimum wage regulations in this setting. A binding minimum wage in the formal sector reduces the size of the formal sector thereby impeding structural transformation. However, output and worker welfare increase initially before decreasing. Since the job destruction in the baseline model is suboptimally low, a binding minimum wage increases job 
destruction which is a source of gain. However, this is offset by the distortionary effect of minimum wage on the profit of entrepreneurs. A binding minimum wage reduces the profit in the formal sector, and hence, the mass of entrepreneurs in the formal sector is decreasing in minimum wage. The latter effect starts dominating soon, and it turns out that a binding minimum wage doesn't achieve production efficiency in the model.

In addition to the theoretical model, the paper also provides some empirical evidence on the relationship between labor market regulations and the share of informal employment using crosscountry data. The share of informal employment is obtained from the International Labour Organization's (ILO) Key Indicators of the Labor Market (KILM) database while the measures of labor market regulations are obtained from the data set developed by the Centre for Business Research of the University of Cambridge. The key empirical result is that stricter dismissal regulations and higher minimum wages increase informality but more generous severance payments do not. These empirical results are broadly consistent with the theoretical results.

The remainder of the paper is organized as follows. The next section provides a brief survey of the related literature. Section III sets up the baseline model and derives the decentralized equilibrium. Section IV sets up the planner's problem to study the efficiency properties of the decentralized outcome. Section $\vee$ studies labor market regulations which is followed by empirical evidence in section VI. Section VII provides concluding remarks.

\section{RELATED LITERATURE}

Fugazza and Jacques (2004) construct a theoretical model where the informal sector doesn't comply with regulations and tax contributions. Workers face a subjective cost of working in the informal sector. There is directed search by workers, and therefore, workers with low subjective cost work in the informal sector while those with high cost work in the formal sector. In equilibrium, firms are indifferent between opening vacancies in the two sectors. The key result is that an increase in tax or social security contributions increases informality while increased enforcement reduces informality.

In Zenou (2008) there are two sectors: formal with search frictions and informal with competitive wages. Workers are identical and freely mobile between the two sectors. In the informal sector, there is diminishing returns to labor which makes the supply of labor to each sector endogenous. In addition to the search frictions, the formal sector has an entry cost or vacancy cost and unemployment benefits. He performs comparative statics with respect to unemployment benefits, hiring costs, etc. and finds the expected results on the incidence of informality.

In de Paula and Scheinkman (2007), agents choose to become a formal sector entrepreneur or an informal sector entrepreneur or a worker. Agents differ in their entrepreneurial ability. Firms in both sectors hire capital and the cost of capital is lower for formal sector firms but they also have to pay a tax. Informal entrepreneurs can evade taxation but they are caught with a positive probability in which case the entire output is seized. The probability of getting caught depends on the size of capital. Therefore, firms requiring more capital are in the formal sector while others are in the informal sector. The highest ability entrepreneurs set up firms in the formal sector, middle ability entrepreneurs in the informal sector and those with lowest entrepreneurial ability decide to become workers. The authors perform comparative static exercises with respect to the rate of taxation and the rate of interest. 
Albrecht, Navarro, and Vroman (2009) introduce ex-ante worker heterogeneity with respect to worker productivity in the formal sector and only high-productivity workers work in the formal sector while others work in the informal sector. There is exogenous job destruction in the informal sector as in a standard Pissarides model but the job destruction is endogenous in the formal sector in response to an idiosyncratic productivity shock. Firms have to pay a severance tax in the formal sector in addition to a payroll tax. Severance tax increases average employment duration in the formal sector, reduces overall unemployment, reduces the number of formal sector workers, and reduces the number of workers who accept any type of offer. A payroll tax reduces average employment duration in the formal sector, reduces the number of formal sector workers, and increases the size of the informal sector and the number of workers accepting any type of offer. Total unemployment rises. Severance tax decreases average productivity while the payroll tax increases it, but under both policies, net output falls.

In Bosch and Esteban-Pretel (2012) formal employment contracts involve a hiring cost, payroll tax, and a firing tax upon job destruction while informal jobs do not incur these costs but are destroyed at a higher rate. Informal jobs are also subject to government monitoring. They are detected with some probability, in which case the job is destroyed and a fine is paid. Informal workers are allowed on the job search for a formal job. Informal jobs arise because for some low productivity matches it is optimal for firms and workers to establish an informal relationship that circumvents formal regulations. Ongoing formal and informal matches draw new idiosyncratic productivity at differential rates (the rate being higher in the informal sector accounting for the higher job destruction there). In this setting, policies that decrease the cost of formal jobs, or increase the cost of informality, raise the share of formal employment while reducing unemployment.

In Meghir, Narita, and Robin (2015), firms in the formal sector are subject to corporate tax on profits, social security contributions for their workers, and severance payments upon laying them off, and have to pay a minimum wage. Workers in the formal sector are subject to income tax and are eligible for unemployment insurance funded by taxes. Firms in the informal sector are monitored and if caught, pay a fine. Firms differ in their productivity, post a wage and choose a sector in which to post vacancies. Workers are homogeneous and meet with firms randomly and accept or reject the wage offer. It is shown that tighter enforcement leads to less informality and higher output.

As far as the empirical evidence on the impact of labor regulations on informality is concerned, Chatterjee and Kanbur (2014) use firm-level data from the Annual Survey of Industry (ASI) and National Sample Survey Organisation (NSSO) to study informality in India. While the ASI data captures firms registered under the Factories Act-which requires firms with more than 10 workers to be registered-the NSSO data is a survey of unregistered firms. Any firm in the NSSO data with 10 or more workers is noncompliant with the Factories Act. There may also be some NSSO firms with nine workers who stay small and informal precisely to evade regulations. The authors find that the NSSO firms with employment of nine or more workers constitute $2 \%$ of all firms and $11 \%$ of employment. ${ }^{2}$

To sum up, the existing literature either doesn't have job destruction by firms and hence cannot talk about employment protection-related policies or if they allow for job destruction as in Meghir, Narita, and Robin (2015), then workers are risk neutral in which case there is no need for employment protection. That is, while several papers in the literature examine the role of employment protection policies on informality and aggregate output, the rationale for employment protection (risk

2 The NSSO firms with 10 or more workers account for $1.5 \%$ of all firms and $9.8 \%$ of employment. Therefore, the number of firms that are noncompliers is much larger than the number that keep their size low to avoid regulations. 
aversion with missing insurance market) is missing in these studies. Hence, it is difficult to carry out a normative exercise involving employment protection policies.

\section{THE MODEL}

There are two sectors in the economy: a formal sector with a sophisticated production function and an informal sector with a simpler production function. The number of workers is given by $\bar{L}$. Workers can work in the formal sector or informal sector. Workers are risk averse and their utility function is given by $U(c)$, with $U^{\prime}(c)>0$ and $U^{\prime \prime}(c)<0$.

There is a unit mass of entrepreneurs with the distribution of entrepreneurial ability given by $G(\varphi)$. Entrepreneurs have to decide whether to set up a firm in the formal sector or informal sector. Firms in the formal sector face a fixed cost of $F$. A part of this fixed cost could arise from meeting the regulatory requirements of the state (the so-called cost of formalization). The other part of the fixed cost should be thought of as the cost of using a more sophisticated technology. Therefore, in our setting, informality can arise both due to regulatory burden and the unprofitability of modern technology for low ability entrepreneurs.

The production function in the informal sector is given by

$$
Z_{i}(\varphi)=B^{\prime} \varphi^{1-\gamma} L_{i}(\varphi)^{\gamma} ; 0<\gamma<1
$$

where $B^{\prime}$ captures the general productivity of the informal sector and is given by $B^{\prime}=\frac{B^{1-\gamma}}{\gamma^{\prime}}$ where $\gamma^{\prime} \equiv \gamma^{\gamma}(1-\gamma)^{1-\gamma}$. The normalization of the constant productivity term in the above fashion reduces notational clutter. $\varphi$ is the entrepreneurial ability. $0<\gamma<1$ captures the diminishing returns to labor and allows for a determinate firm size. The wage in the informal sector is $w_{i}$ which is determined competitively. Denote the profit of an entrepreneur in the informal sector by $\pi_{i}(\varphi)$.

The optimal choice of labor is given by

$$
\gamma B^{\prime} \varphi^{1-\gamma} L_{i}(\varphi)^{\gamma-1}=w_{i}
$$

Therefore, the amount of labor hired by an entrepreneur with ability $\phi$ is given by

$$
L_{i}(\varphi)=\frac{\gamma}{1-\gamma} \varphi B w_{i}^{\frac{1}{\gamma-1}}
$$

The profit of an informal sector entrepreneur with ability $\phi$ is given by

$$
\pi_{i}(\varphi)=B^{\prime} \phi^{1-\gamma} L(\varphi)^{\gamma}-w_{i} L_{i}(\varphi)=\varphi B w_{i}^{\frac{\gamma}{\gamma-1}}
$$

Clearly, $\pi_{i}(\varphi)$ is increasing in $\varphi$ and decreasing in $w_{i}$.

The formal sector production function is more complicated. Here the productivity of a worker is match specific. Denote the match-specific productivity of a worker by $\lambda$ which is drawn from a 
uniform distribution over [0.1]. Once the match-specific productivity of a worker is revealed, the firm can decide whether to retain the worker or fire them. If firms use a cutoff rule whereby they retain workers with productivity above $\lambda_{c}$ and fire others, then the average productivity of retained workers is $\frac{1+\lambda_{c}}{2}$. If they hire $L_{f}$ workers then they retain $\left(1-\lambda_{c}\right) L_{f}$ of them, and hence the amount of labor in efficiency units that is used in production is

$$
L^{e}=\frac{1-\lambda_{c}^{2}}{2} L_{f}
$$

The production function is

$$
Z(\varphi)=A^{\prime} \varphi^{1-\gamma}\left(\frac{1-\lambda_{c}^{2}}{2}\right)^{\gamma} L_{f}(\varphi)^{\gamma}
$$

where $A^{\prime}$ is the common productivity term and we use the normalization $A^{\prime}=\frac{A^{1-\gamma}}{\gamma^{\prime}} . \varphi$ is the managerspecific productivity term.

A formal sector firm announces a contract $\left(w_{f}, \lambda_{c}\right)$ which must satisfy the following participation constraint of workers.

$$
\left(1-\lambda_{c}\right) U\left(w_{f}\right)+\lambda_{c} U(z) \geq U\left(w_{i}\right)
$$

That is, a worker expects to get a wage of $w_{f}$ with probability $1-\lambda_{c}$ and $z$ (cash equivalent of home production or leisure) with probability $\lambda_{c}$ (in the event that the worker is fired). The expected utility from participating in the formal sector must at least be as high as the utility from working in the informal sector $U\left(w_{i}\right)$. We are assuming that the fired workers cannot work in the informal sector. It is as if workers at the beginning of each period in our static model make a decision whether to work in the informal sector or look for a job in the formal sector with the possibility of being fired and staying unemployed. ${ }^{3}$

Therefore, a firm in the formal sector solves the following maximization problem:

$$
\begin{aligned}
& \operatorname{Max}_{L_{f}(\varphi), w_{f}, \lambda_{c}}\left\{A^{\prime} \varphi^{1-\gamma}\left(\frac{1-\lambda_{c}^{2}}{2}\right)^{\gamma} L_{f}(\varphi)^{\gamma}-w_{f}\left(1-\lambda_{c}\right) L_{f}(\varphi)\right\} \\
& \text { s.t. }\left(1-\lambda_{c}\right) U\left(w_{f}\right)+\lambda_{c} U(z) \geq U\left(w_{i}\right)
\end{aligned}
$$

3 The assumption is similar to the assumption in Zenou (2008) where workers can either work in the informal sector or search for a job in the formal sector. In his dynamic model, the value of unemployment in the formal sector equals the value of a job in the informal sector. Also, for the problem to be meaningful, it must be the case that $w_{i c}>z$ So, the workers who are fired in the formal sector suffer a loss and therefore must be compensated through a higher formal sector wage. 
Denoting the Lagrangian multiplier associated with the constraint by $\rho$, the first-order conditions are

$$
\begin{gathered}
L_{f}(\varphi): A^{\prime} \varphi^{1-\gamma} \gamma\left(\frac{1-\lambda_{c}^{2}}{2}\right)^{\gamma} L_{f}(\varphi)^{\gamma-1}=w_{f}\left(1-\lambda_{c}\right) \\
w_{f}:-\left(1-\lambda_{c}\right) L_{f}(\varphi)+\rho\left(1-\lambda_{c}\right) U^{\prime}\left(w_{f}\right)=0 \\
\lambda_{c}:-A^{\prime} \varphi^{1-\gamma} \gamma \lambda_{c}\left(\frac{1-\lambda_{c}^{2}}{2}\right)^{\gamma-1} L_{F}(\varphi)^{\gamma}=\rho U\left(\left(w_{f}\right)-U(z)\right)-w_{f} L_{f}(\varphi)
\end{gathered}
$$

Using (9) write (10) as

$$
A^{\prime} \varphi^{1-\gamma} \gamma \lambda_{c}\left(\frac{1-\lambda_{c}^{2}}{2}\right)^{\gamma-1} L_{f}(\varphi)^{\gamma-1}=w_{f}-\psi
$$

where $\psi \equiv \frac{U\left(w_{f}\right)-U(z)}{U^{\prime}\left(w_{f}\right)}$.

Therefore, for a formal sector firm with productivity $\varphi$, the three endogenous variables $L_{f}, w_{f}$, and $\lambda_{c}$ are determined by the following three equations:

$$
\begin{gathered}
A^{\prime} \varphi^{1-\gamma} \gamma\left(\frac{1-\lambda_{c}^{2}}{2}\right)^{\gamma} L_{f}(\varphi)^{\gamma-1}=w_{f}\left(1-\lambda_{c}\right) \\
A^{\prime} \varphi^{1-\gamma} \gamma \lambda_{c}\left(\frac{1-\lambda_{c}^{2}}{2}\right)^{\gamma-1} L_{f}(\varphi)^{\gamma-1}=w_{f}-\psi \\
\left(1-\lambda_{c}\right) U\left(w_{f}\right)+\lambda_{c} U(z)=U\left(w_{i}\right)
\end{gathered}
$$

for a given $w_{i}$. Note that (12) and (13) imply

$$
\frac{1+\lambda_{c}}{2 \lambda_{c}}=\frac{W_{f}}{W_{f}-\psi}
$$

Equations (14) and (15) determine $w_{f}$ and $\lambda_{c}$ independent of $\varphi$ the firm productivity parameter. That is, each formal sector firm offers the same $\left(w_{f}, \lambda_{c}\right)$ contract. The amount of labor hired by a formal sector firm is

$$
L_{f}(\varphi)=\frac{\gamma}{1-\gamma} \varphi A\left(\frac{1-\lambda_{c}^{2}}{2}\right)^{\frac{\gamma}{1-\gamma}}\left(w_{f}\left(1-\lambda_{c}\right)\right)^{\frac{1}{\gamma-1}}
$$


Thus, in the model, a high-productivity firm is larger but pays the same wage and has the same firing threshold.

Denote the profit gross of the fixed cost of operations of a formal sector firm by $\pi_{f}(\varphi)$ which is given as follows:

$$
\pi_{f}(\varphi)=\varphi A\left(\frac{1+\lambda_{c}}{2 w_{f}}\right)^{\frac{\gamma}{1-\gamma}}
$$

The net return from entrepreneurship in the formal sector is $\pi_{f}(\varphi)-F$. The marginal entrepreneur with entrepreneurial ability $\varphi^{*}$ is indifferent between setting up a firm in the formal sector or in the informal sector, and this indifference condition is given by

$$
\pi_{f}\left(\varphi^{*}\right)-\pi_{i}\left(\varphi^{*}\right) \equiv \varphi^{*}\left(A\left(\frac{1+\lambda_{c}}{2 w_{f}}\right)^{\frac{\gamma}{1-\gamma}}-B w_{i}^{\frac{\gamma}{\gamma-1}}\right)=F
$$

Entrepreneurs with $\varphi<\varphi^{*}$ open firms in the informal sector, while the rest open firms in the formal sector.

We assume that the parameters are such that the following condition is satisfied in equilibrium:

$$
A^{\frac{1-\gamma}{\gamma}}\left(\frac{1+\lambda_{c}}{2 W_{f}}\right)>B^{\frac{1-\gamma}{\gamma}}\left(\frac{1}{W_{i}}\right)
$$

The condition above ensures that in the absence of the fixed cost $F$, all entrepreneurs would wish to set up firms in the formal sector and is satisfied if $A$ is sufficiently higher than $B$. In this case, it is the fixed costs of setting up business in the formal sector that prevents some low ability entrepreneurs to enter the formal sector. As mentioned earlier, a part of the fixed cost is technological and a part could be regulation related. In this case, there will be some informality due to technological reasons and the rest can be attributed to regulations.

The total employment in the informal sector is given by

$$
L^{\prime}=\int_{\underline{\varphi}}^{\varphi^{*}} L_{i}(\varphi) d G(\varphi)
$$

where $L_{i}(\varphi)$ is given by (3). Similarly, the employment in the formal sector is given by

$$
L^{F}=\int_{\varphi^{*}}^{\bar{\varphi}} L_{f}(\varphi) d G(\varphi)
$$


where $L_{f}(\varphi)$ is given in (16). Since the total amount of labor in the economy is $\bar{L}$, the following must be true:

$$
L^{\prime}+L^{F}=\bar{L}
$$

The model above has the following endogenous variables: $w_{f}, \lambda_{c}, w_{i}, \varphi^{*}, L^{\prime}, L^{F}$. They will be functions of the exogenous variables: $A, B, F$, and $L$. Equations (14), (15), (18), (20), (21), and (22) determine the six endogenous variables of interest.

$L^{\prime}$ and $L^{F}$ give us the sizes of the two sectors in terms of employment. $w_{f}$ and $w_{i}$ are the wages in the two sectors, and $\lambda_{c}$ is the unemployment rate in the formal sector. Since there is a possibility of unemployment in the formal sector, the wage in the formal sector must be higher than that in the informal sector: $w_{f}>w_{i}$.

Denote the aggregate output in the informal sector by $Z^{\prime}$ and the aggregate output in the formal sector by $Z^{F}$. Net output for the economy, which is our measure of production efficiency, is given by

$$
Y=Z^{\prime}+Z^{F}+\lambda_{c} L^{F} Z-\left(1-G\left(\phi^{*}\right)\right) F
$$

where the term $\lambda_{c} L^{F} z$ is the home production of fired workers and the last term is the fixed cost of formal sector firms.

In the comparative statics below, our variables of interest will be the net output, $Y$, the share of the formal sector in labor force, $L^{F}$, and the welfare of workers, $U\left(w_{i}\right)$.

\section{PLANNER'S PROBLEM}

To show how the risk aversion of workers combined with a missing market for insurance against labor income risk creates production inefficiency in the economy, we set up the problem for a planner who is interested in maximizing the aggregate output (23). The planner will have to allocate both labor and entrepreneurs to the two sectors to maximize aggregate output. The planner recognizes the limited span of control of entrepreneurs (diminishing returns to labor) and also the fixed cost, $F$, that each entrepreneur has to incur to start a business in the formal sector. The planner undertakes the following maximization exercise.

$$
\operatorname{Max}_{\lambda_{c}(\varphi), L_{f}(\varphi), L_{i}(\varphi), \varphi^{*}}\left\{\begin{array}{c}
B^{\prime} \int_{\underline{\varphi}}^{\varphi^{*}} \varphi^{1-\gamma} L_{i}(\varphi)^{\gamma} d G(\varphi)+A^{\prime} \int_{\varphi^{*}}^{\bar{\varphi}}\left(\frac{1-\lambda_{c}(\varphi)^{2}}{2}\right)^{\gamma} \varphi^{1-\gamma} L_{f}(\varphi)^{\gamma} d G(\varphi) \\
+z \int_{\varphi^{*}}^{\bar{\varphi}} \lambda_{c}(\varphi) L_{f}(\varphi) d G(\varphi)-\left(1-G\left(\varphi^{*}\right)\right) F+\mu\left(\bar{L}-L^{\prime}-L^{F}\right)
\end{array}\right\}
$$


The details of the planner's maximization exercise are given in the appendix. What is notable is that the solution to the planner's problem corresponds to the decentralized outcome when workers are risk neutral. That is, in the risk-neutral worker case, the allocation of resources between the formal and informal sectors in the planner's problem corresponds to the decentralized outcome. Therefore, in the baseline model, the distortion in the decentralized case arises due to the risk aversion of workers.

While we have proved analytically that when workers are risk averse, the decentralized outcome is production inefficient, we have not answered the question of the direction of inefficiency: Are there too many workers in the formal sector or too few workers? We verify numerically that with risk-averse workers, the aggregate net output is lower than in the planner's problem and there are too few workers in the formal sector. More precisely, we verify that the aggregate net output is decreasing in the degree of risk aversion as is the share of workforce in the formal sector. Additionally, the fraction of entrepreneurs operating in the formal sector is smaller as is the welfare of workers. Finally, when workers are risk averse, firms choose a much lower $\lambda_{c}$ compared to what the planner chooses. These results are verified in Figure 1. In Figure 1, as well as in all other numerical examples in the paper, we assume a constant relative risk aversion utility function of the following form: $U(x)=\frac{x^{1-\rho}-1}{1-\rho}$ where $\rho$ is the risk aversion parameter. In Figure 1, the planner's outcome corresponds to the risk-neutral outcome (where $\rho=0$ ). Figures 1a-1f show that the following variables of interest are decreasing in the degree of risk aversion: aggregate net output, share of workforce in the formal sector, share of entrepreneurs in the formal sector, rate of job destruction, rate of unemployment, and worker welfare.

Intuitively, when workers are risk averse and markets for insurance are missing, firms have to pay workers a higher wage to meet their reservation utility given that they may be fired. As a result, the level of $\lambda_{c}$ chosen by firms in a decentralized equilibrium is less than what is optimal from the production efficiency point of view. This also reduces the profitability of firms in the formal sector leading to fewer entrepreneurs and workers in the formal sector.

So far, we have not allowed firms to offer severance payments voluntarily. We have restricted the contracts offered by the firms in the formal sector to a $\left(w_{f}, \lambda_{c}\right)$ pair. What if firms can offer severance payments voluntarily or if the government mandates severance payments? We verify below that production efficiency can be attained through severance payments. 
Figure 1: Risk Aversion and Labor Market Outcomes

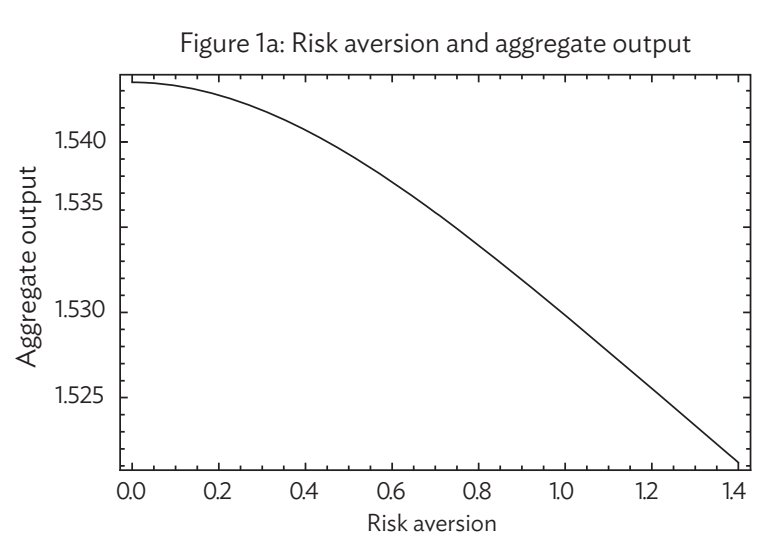

Figure 1b: Risk aversion and share labor force

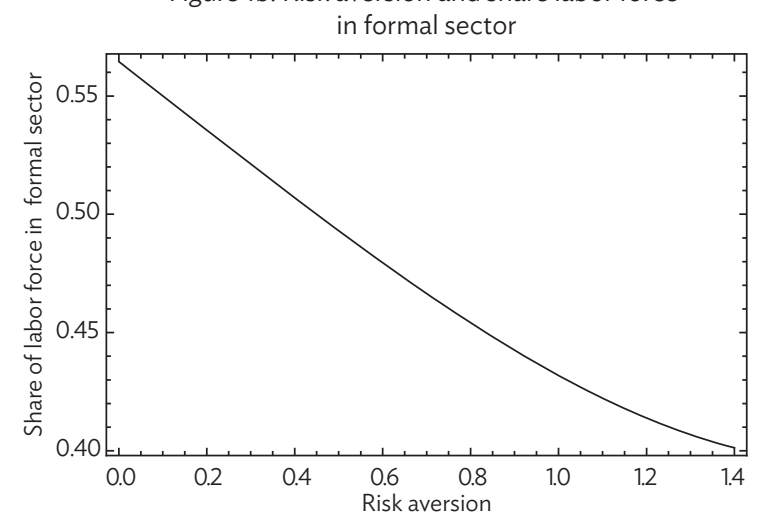

Figure 1c: Risk aversion and share entrepreneur

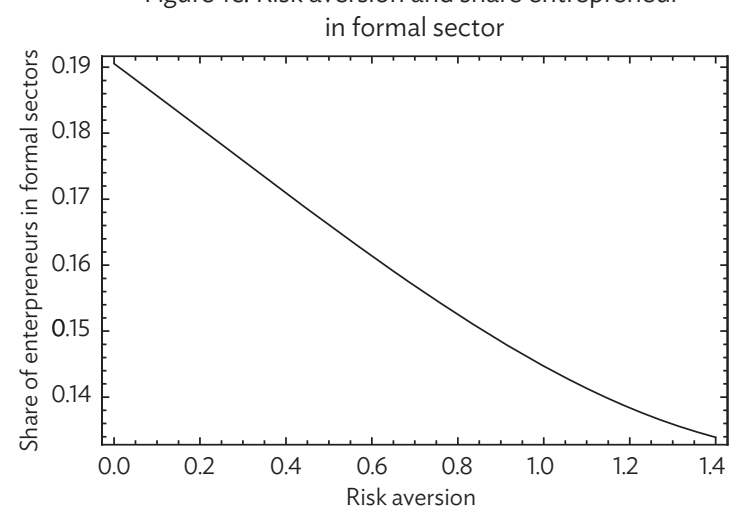

Figure 1d: Risk Aversion and job destruction

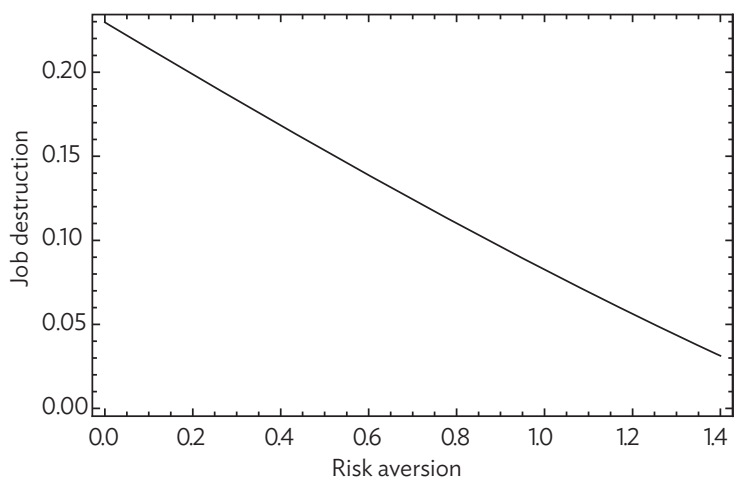

Figure 1e: Risk aversion and unemployment
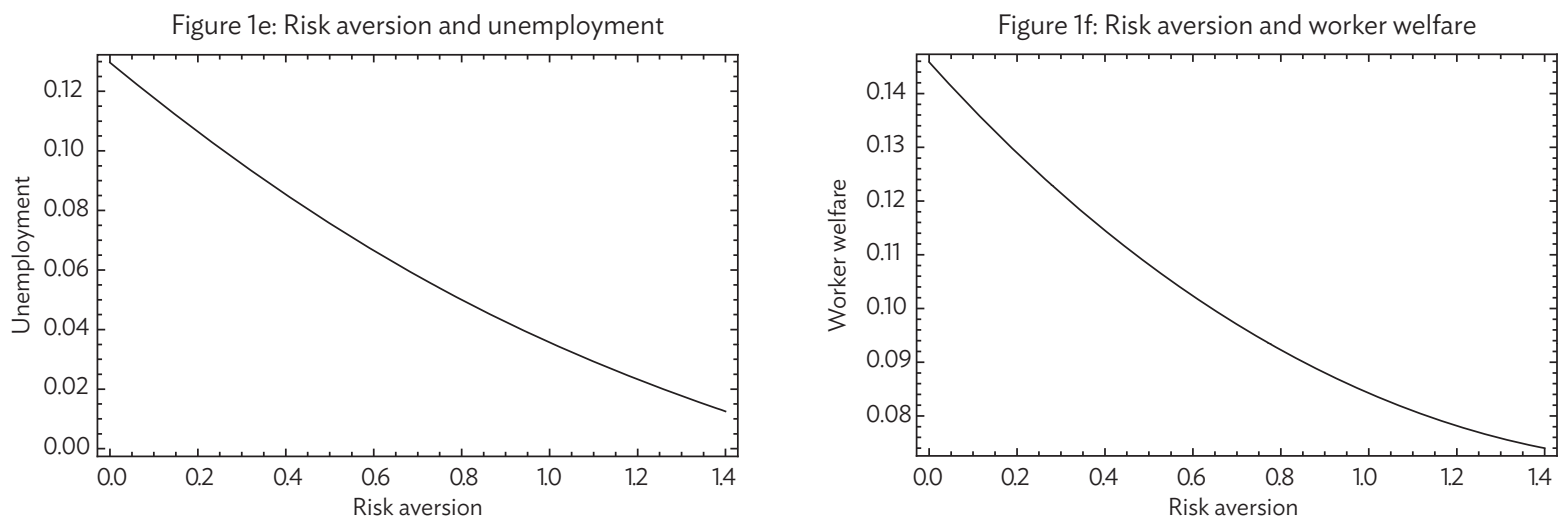

$A=8, B=1, L=1, \gamma=2 / 3, z=.5, F=.75$

Source: Authors' calculations. 


\section{LABOR MARKET REGULATIONS}

\section{A. Severance Payments/Unemployment Insurance}

Suppose firms can offer severance payments voluntarily. This takes the form of a payment, $s$, to each fired worker. So, firms offer a contract $\left(w_{f}, s, \lambda_{c}\right)$ where $s$ is the severance payment promised to each fired worker. Now, the firms in the formal sector will do the following maximization exercise:

$$
\begin{aligned}
& \operatorname{Max}_{L_{f}, w_{f}, \lambda_{c}, s}\left\{A^{\prime} \varphi^{1-\gamma}\left(\frac{1-\lambda_{c}^{2}}{2}\right)^{\gamma} L_{f}(\varphi)^{\gamma}-w_{f}\left(1-\lambda_{c}\right) L_{f}(\varphi)-\lambda_{c} L_{f}(\varphi) s\right\} \\
& \text { s.t. }\left(1-\lambda_{c}\right) U\left(w_{f}\right)+\lambda_{c} U(s+z) \geq U\left(w_{i}\right)
\end{aligned}
$$

The equations for this case are derived in the appendix. It is shown that the optimal choice of severance payments by firms is characterized by $w_{f}=s+z$. That is, firms fully insure workers against unemployment risk. This level of severance payments also ensures production efficiency. Intuitively, the key distortion in the baseline model discussed earlier is the lack of insurance for risk-averse workers. Since severance payments involve a transfer from risk-neutral firms to risk-averse workers, they are efficiency enhancing.

Since firms have an incentive to offer severance payments voluntarily, there is no need for a mandate. However, if firms suffer from a credibility problem, a promise to pay severance payments in the future in exchange for lower wages now may not be credible. If there are credibility problems associated with a firm's promise, then a government mandate can have a role. If the government mandates severance payments at the appropriate level, production efficiency will be restored.

Figure 2 shows the impact of a mandated severance payment on the labor market outcomes of interest. The relationship between severance payments and the labor market outcomes of interest is nonlinear. Aggregate net output, share of labor in the formal sector, and worker welfare increase with severance payments and then they start decreasing beyond a point. The turning point comes at the level of severance payments that fully insures workers and is also the production-efficient level of severance payments. Any severance payments in excess of this is counterproductive.

A nonlinear relationship obtains between unemployment and the level of severance payments as well. Note that the impact on unemployment is a composite effect of changes in the share of labor in the formal sector and the rate of job destruction by the firms. As shown in Figure $2 \mathrm{~d}$, the rate of job destruction increases first and then decreases with severance payments as does the rate of unemployment shown in Figure 2e.

Figure 2 clearly shows the efficiency-enhancing role of severance payments. A small severance payment increases aggregate output and promotes structural transformation. It increases worker welfare even though the unemployment rate increases. Figure $2 c$ shows the impact of severance payments on the fraction of entrepreneurs in the formal sector. Since this corresponds to the number of firms in the formal sector, this can be thought of as the impact of severance payments on the extensive margin of employment. One advantage of our large firm model is that we can study the implications of a policy on firm-level employment as well, that is, we can study the impact of a policy on the intensive margin as well. Figure $2 g$ shows the impact of severance payments on the intensive 
margin (firm level) of employment. Figure 2 g compares firm-level employment in the absence of any policy with the firm-level employment when optimal severance payments are in place. The solid black captures the no policy intervention case while the dashed line captures the optimal severance payments case. The line to the left of the point of discontinuity captures the employment of informal firms while the line to the right captures the employment of formal sector firms. The point of discontinuity is lower with optimal severance payment which simply captures the extensive margin effect. That is, there are more formal sector firms with optimal severance payments. For a given level of productivity, the employment of formal sector firms is higher with optimal severance payments than without it. For informal sector firms, the opposite is true. That is, they have higher employment with no policy than with optimal severance payments. The reason is that the informal wage is higher in the optimal severance payments case than without it. Therefore, optimal severance payments increase formal sector employment both at the extensive and intensive margins.

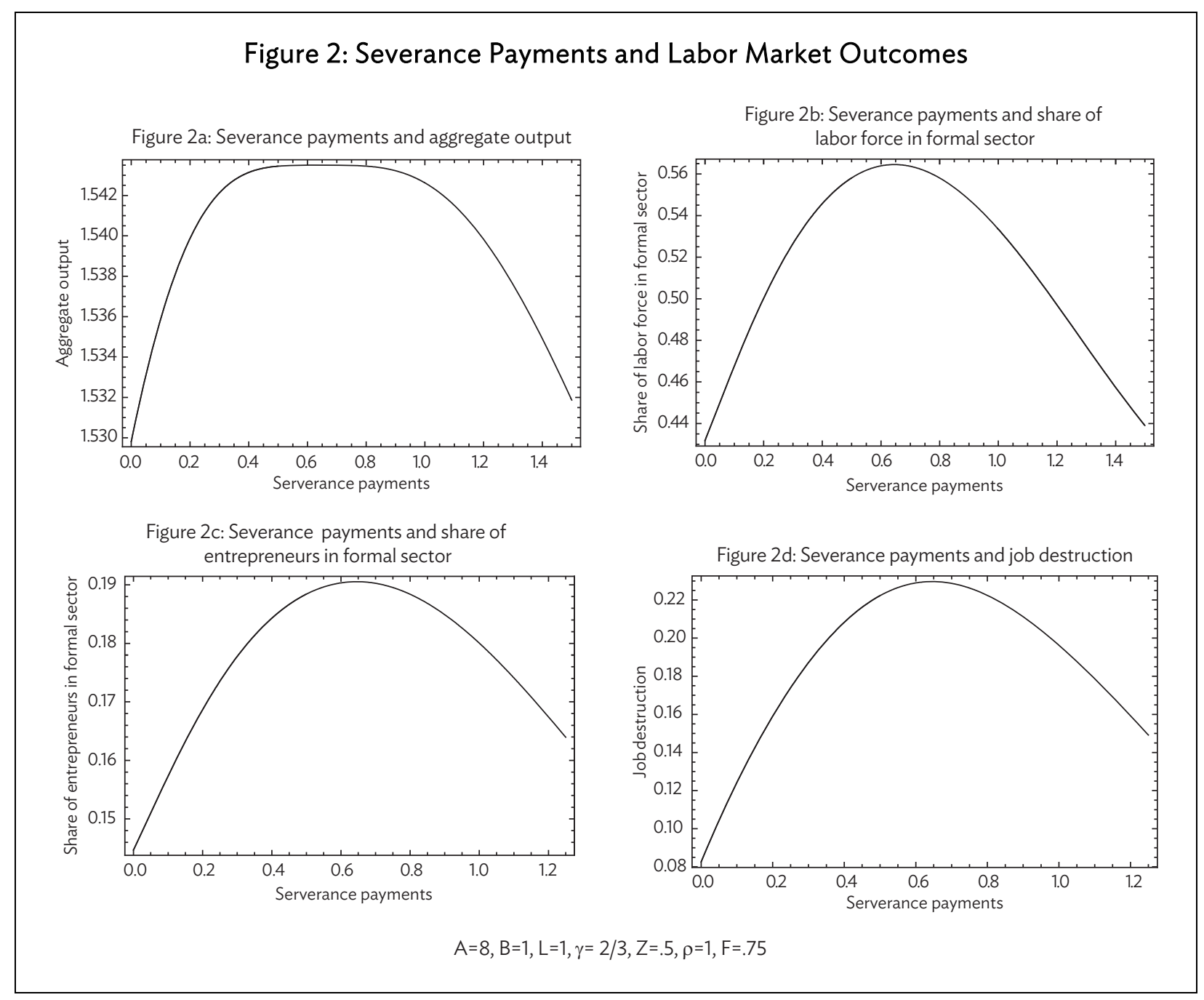


Figure 2: continued
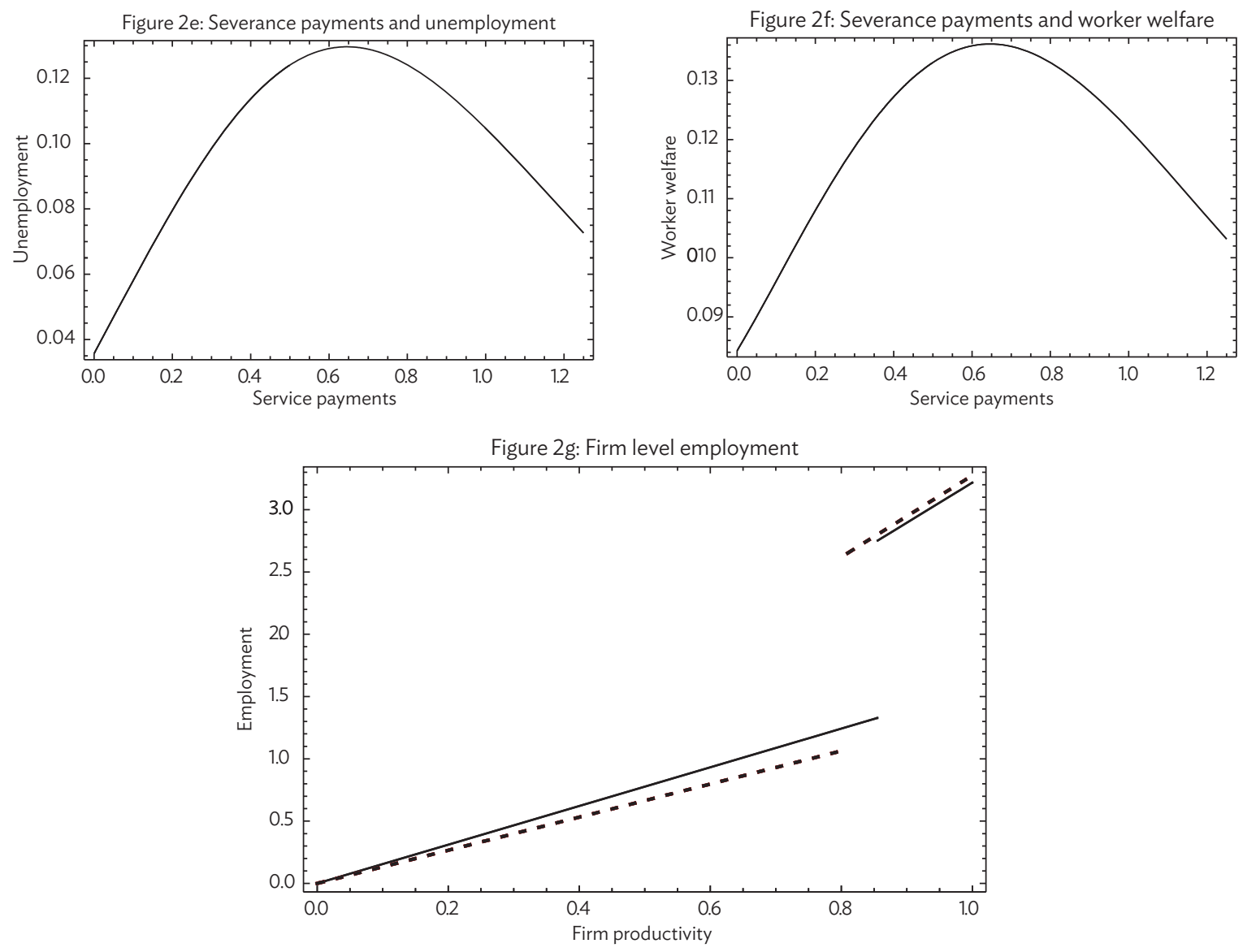

$A=8, B=1, L=1, \gamma=2 / 3, Z=.5, \rho=1, F=.75$

Source: Authors' calculations.

While we have talked about mandated severance payments as a policy intervention, it is equivalent to an unemployment insurance program funded by a layoff tax. So, suppose the government imposes a layoff tax of $s$ and transfers the proceeds to unemployed workers. The outcome is equivalent to the case when $s$ is the level of mandated severance payments. While the two are equivalent theoretically, one or the other may be superior in practice. Mandated severance payments may suffer from noncompliance, either willful or because of the inability of a firm to pay it during crises. In this case, an unemployment insurance funded by a layoff tax may be preferable. The US unemployment insurance program with experience-rated contribution has this feature.

\section{B. Noncompliance, State Capacity, etc.}

While the theoretical model shows the equivalence between severance payments and unemployment insurance funded by a layoff tax, mandated severance payments may suffer from noncompliance problems as happened during the financial crisis in the Republic of Korea. In this case, a governmentprovided insurance funded by a layoff tax may be superior. The downside of state-provided unemployment insurance is that it may run into weak state capacity. One way to model weak state 
capacity would be to assume that when government collects money from firms, only a fraction $\phi$ is given back to workers as benefits. The remaining fraction $1-\phi$ is lost due to corruption, mismanagement, etc. $\phi=1$ will capture strong state capacity.

In this case the maximization exercise for firms is modified as follows:

$$
\begin{aligned}
& \operatorname{Max}_{L_{f}, w_{f}, \lambda_{c}}\left\{A^{\prime} \varphi^{1-\gamma}\left(\frac{1-\lambda_{c}^{2}}{2}\right)^{\gamma} L_{f}(\varphi)^{\gamma}-w_{f}\left(1-\lambda_{c}\right) L_{f}(\varphi)-\lambda_{c} L_{f}(\varphi) s\right\} \\
& \text { s.t. }\left(1-\lambda_{c}\right) U\left(w_{f}\right)+\lambda_{c} U(\phi s+z) \geq U\left(w_{i}\right)
\end{aligned}
$$

The above captures the fact that while the layoff tax is $s$, a fired worker actually gets $\phi s<s$. Clearly, this would reduce the effectiveness of unemployment insurance. In the appendix, we verify that if firms offer severance payments voluntarily, the privately optimal level of severance payments (or unemployment insurance funded by an equivalent layoff tax) fails to restore production efficiency. The privately optimal level of $s$ doesn't provide full insurance:

$$
w_{f}>\phi s+z
$$

We verify numerically that if the level of $\phi$ is too low, that is the leakage is sufficiently high, then firms do not want to offer any severance payments voluntarily. Additionally, the outputmaximizing level of severance payments is zero in this case. That is, even a policy maker doesn't want to mandate severance payments or provide unemployment insurance through a layoff tax in this case.

Next, we study firing restrictions in the model and show how the results differ from severance payments.

\section{Administrative Burden of Firing}

To see how we can study firing restrictions in the model, suppose that firms in the formal sector have firing costs which are in the nature of administrative burden denoted by $b$. It is important to note that the administrative burden is not a transfer to workers. The administrative burden of firing $b$, should be distinguished from the severance payments, $s$. The latter are a transfer to workers while the former simply makes it costlier for firms to fire workers. It should be thought of as the cost of complying with the firing regulations.

Now firms do the following maximization exercise:

$$
\begin{aligned}
& \operatorname{Max}_{L_{f}, w_{f}, \lambda_{c}}\left\{A^{\prime} \varphi^{1-\gamma}\left(\frac{1-\lambda_{c}^{2}}{2}\right)^{\gamma} L_{f}^{\gamma}-w_{f}\left(1-\lambda_{c}\right) L_{h}-\lambda_{c} b L_{f}\right\} \\
& \operatorname{s.t}\left(1-\lambda_{c}\right) U\left(w_{f}\right)+\lambda_{c} U(z) \geq U\left(w_{i}\right)
\end{aligned}
$$

The key equations for this case are derived in the appendix. Figure 3 provides results for how the variables of interest change in response to a change in $b$. Note from Figure $3 a$ that the administrative burden of firing results is a decrease in aggregate net output. This happens because it 
causes more resources to flow to the informal sector thereby impeding the process of structural transformation. As shown in Figure 3b, the share of workers in the formal sector decreases as the administrative burden of firing increases as does the share of entrepreneurs in the formal sector shown in Figure 3c. Figure $3 d$ shows that the rate of job destruction decreases as does the rate of unemployment shown in Figure $3 e$. The decrease in unemployment is a consequence of the decrease in firing, $\lambda_{c}$, shown in Figure $3 \mathrm{~d}$, as well as the decrease in the share of workers working in the formal sector, shown in Figure $3 \mathrm{~b}$, which is the only sector that has unemployment. Interestingly, an increase in the burden of firing also decreases the welfare of workers as shown in Figure $3 f$. Therefore, not only is this policy inefficient from the point of view of production efficiency, but the general equilibrium effect is such that the welfare of workers decreases as well. Therefore, it fails to provide protection to workers in addition to impeding structural transformation.

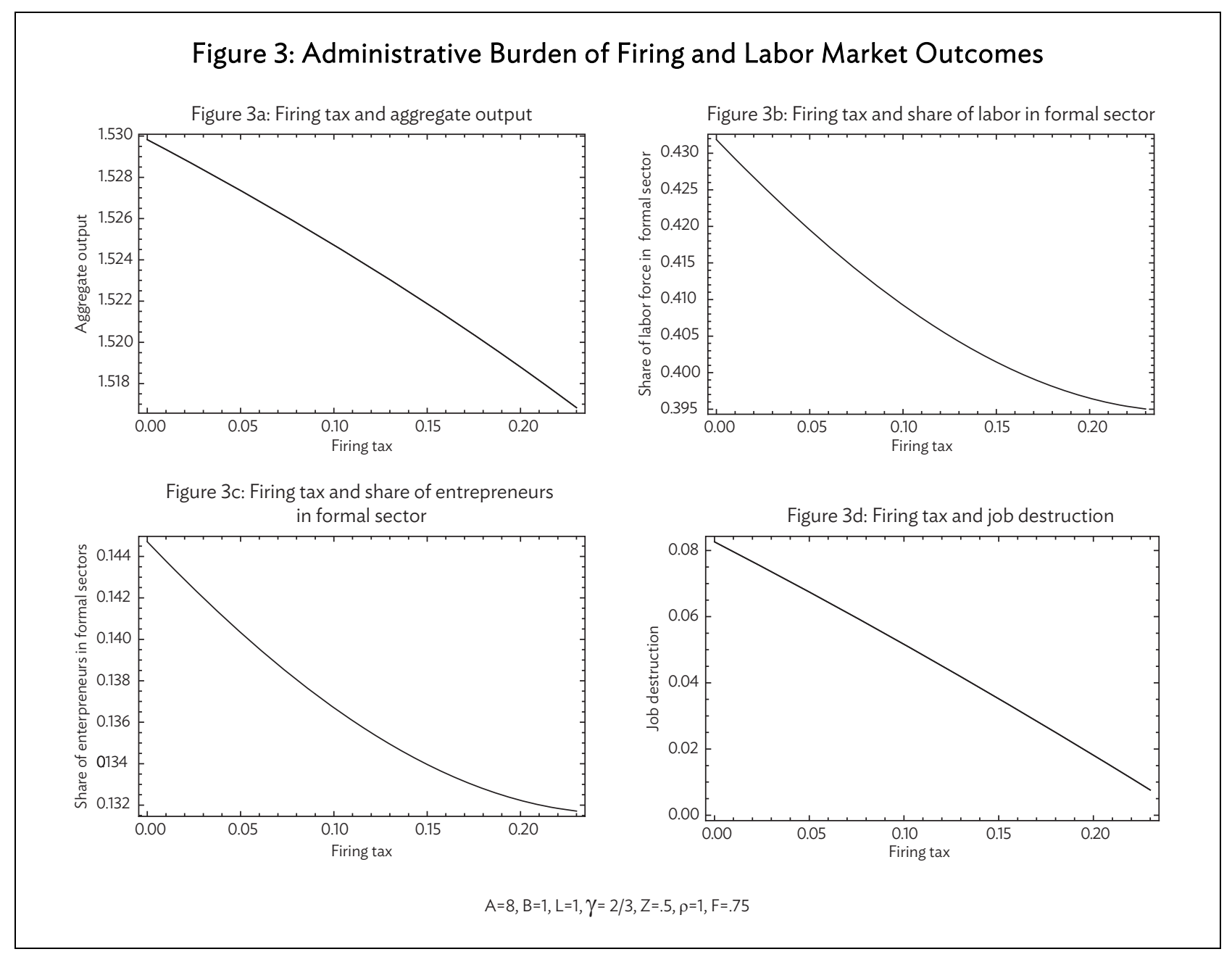

continued on next page 
Figure 3: continued
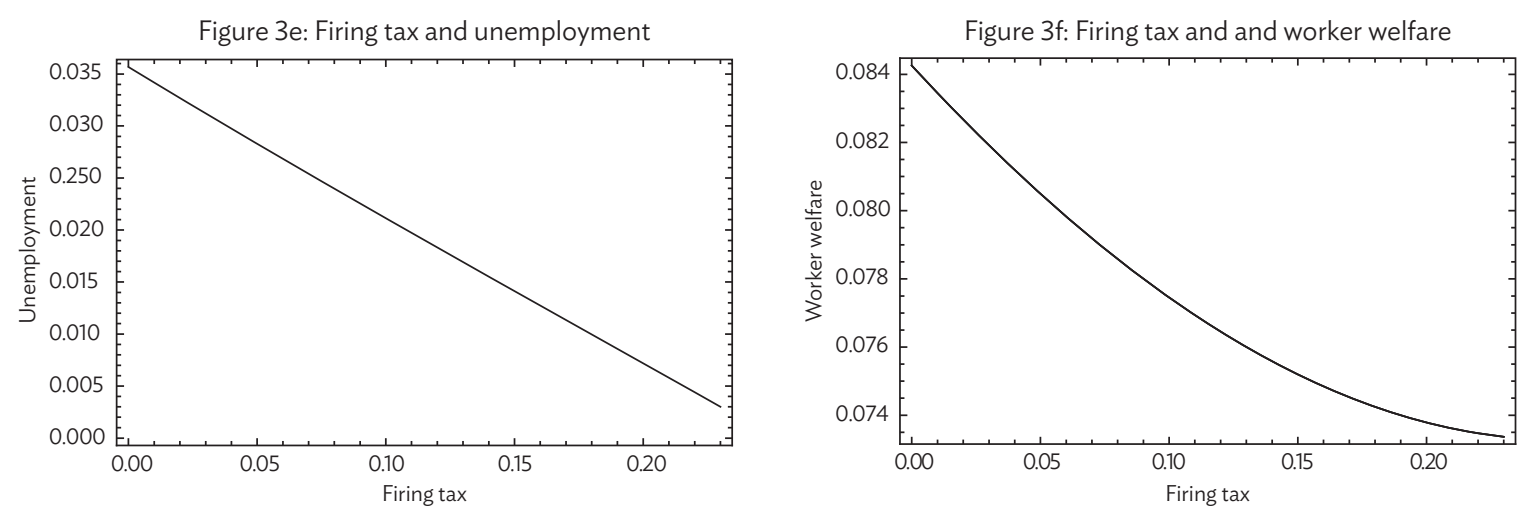

Figure 3g: Firm level employment

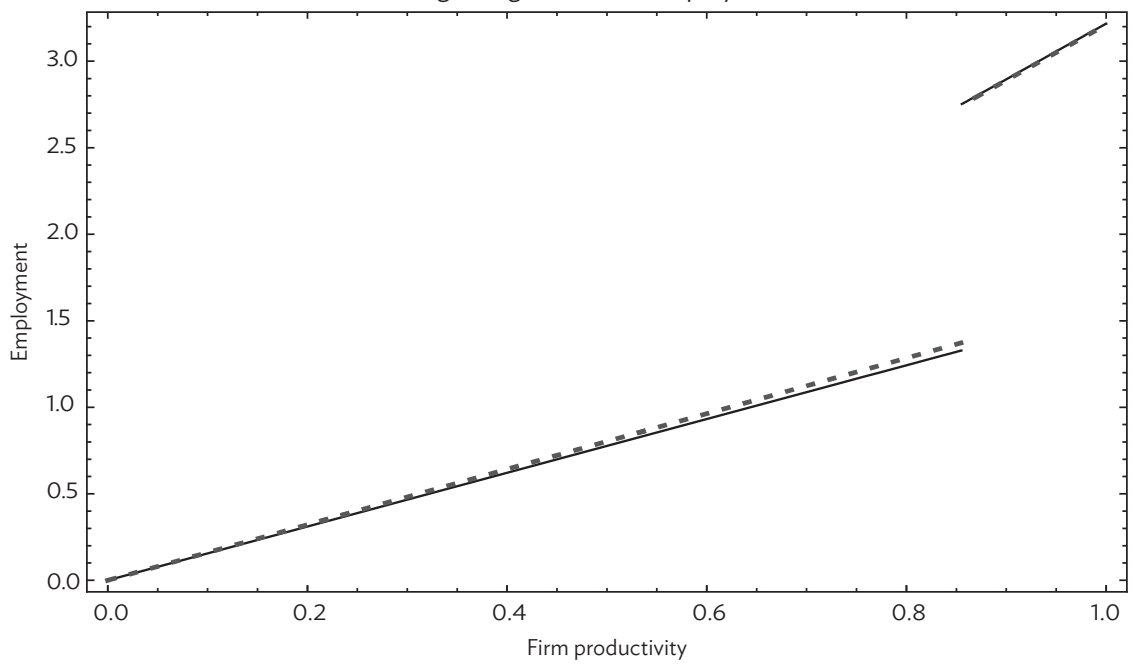

$A=8, B=1, L=1, \gamma=2 / 3, Z=.5, \rho=1, F=.75$

Source: Authors' calculations.

Analogous to Figure $2 g$ discussed earlier, Figure $3 g$ shows the impact of the administrative burden of firing on the intensive margin (firm level) of employment. The point of discontinuity is higher with the burden of firing which captures the extensive margin effect shown in Figure $3 \mathrm{c}$. That is, there are less formal sector firms if firing workers is onerous. Moreover, for a given level of productivity, the employment of formal sector firms is lower with firing burden than without it. For informal sector firms, the opposite is true. That is, they have higher employment with firing burden than no policy because the informal sector wage is lower with firing burden. Therefore, the administrative burden of firing decreases formal sector employment both at the extensive and intensive margins.

Anecdotal evidence suggests that it is difficult for formal sector firms to fire workers in many developing countries including India and Sri Lanka. That is, $b$ is high enough that $\lambda_{c} \rightarrow 0$. The result in Figure 3 suggests that this policy is clearly inefficient and more importantly it fails to raise the welfare of workers who are the intended beneficiaries of such policies. 
To sum up, while the administrative burden of firing that are not a transfer to workers are counterproductive, severance payments or unemployment insurance funded by a layoff tax have an important insurance role which promotes structural transformation.

\section{Increase in General Regulatory Burden}

Any regulation that reduces the incentive to enter the formal sector slows down structural transformation. The effects of a general regulatory burden such as the ease of doing business can be captured through $F$. An increase in $F$ reduces the attractiveness of the formal sector and therefore, hinders structural transformation. A decrease in $F$ can capture the ease of doing business or it could capture a technological change that allows firms to operate at a smaller scale, making smaller firms viable in the formal sector.

Figure 4 captures the impact of a change in $F$ on several variables of interest. It is shown that the aggregate output (Figure $4 a$ ), the share of workers in the formal sector (Figure 4b), and the share of entrepreneurs in the formal sector (Figure 4c) decrease with $F$. It turns out that the wage that firms pay in the formal sector, $w_{f}$, is decreasing in $F$. The firing rate, $\lambda_{c}$, increases with $F$ as shown in Figure $4 \mathrm{~d}$. A consequence of an increase in the firing rate and a decrease in the share of workforce in the formal sector in response to an increase in $F$ is that the rate of unemployment becomes nonmonotonic as shown in Figure 4e. Finally, the welfare of workers decreases with $F$ as is verified in Figure $4 f$.

Therefore, a reduction in regulatory burden not only promotes structural transformation and thereby increases aggregate net output, it also increases worker welfare. That is, workers in both sectors gain.

The model that we have developed in the paper can also study the implications of regulations/policies that become applicable for firms above a certain size. For example, the Factories Act in India requires firms (using power) with more than 10 workers to register. Similarly, the Industrial Disputes Act in India requires firms employing more than 50 workers to provide severance payments and firms employing more than 100 workers to seek permission from the government before firing any worker. In Sri Lanka, the firing restrictions apply to firms with 15 or more workers.

To see the implications of such regulations in the context of our model suppose the firm size above which the firing regulation is binding is $\hat{L}$. The qualitative results are going to be similar to the ones described above. One difference will be that now some formal sector firms will have an incentive

to reduce their firm size to $\hat{L}$ to avoid paying firing taxes. That is, the size distribution of formal sector firms will have a hole around $\hat{L}{ }^{4}$

4 Abidoye, Orazem, and Vodopivec (2014) find evidence that some firms in Sri Lanka try to keep the firm size below the threshold where firing restrictions start binding. 


\section{Figure 4: Regulatory Burden and Labor Market Outcomes}

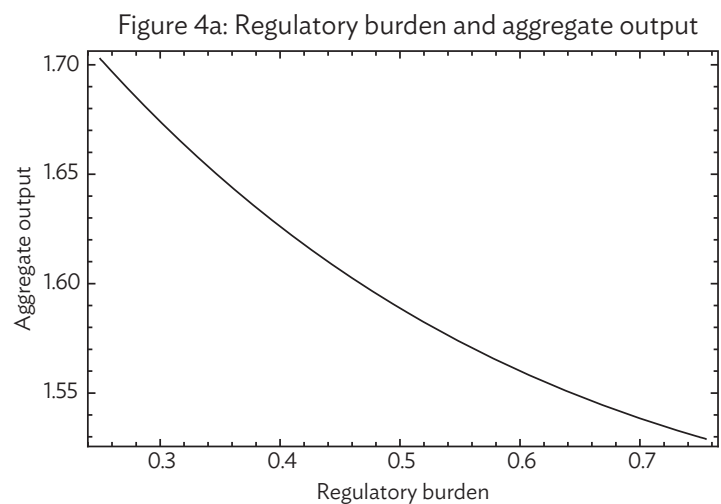

Figure 4c: Regulatory burden and share of entrepreneurs in formal sector

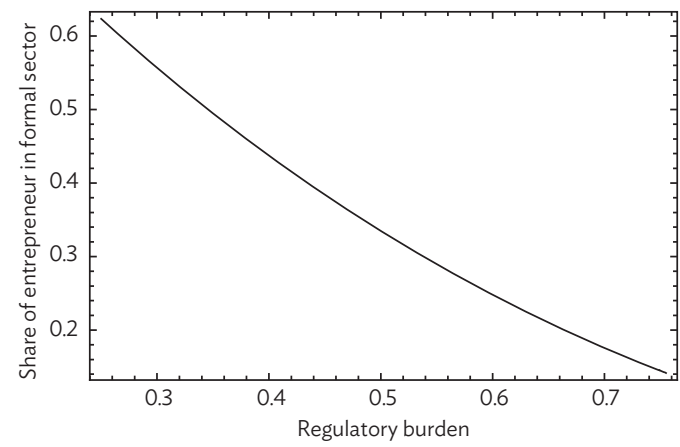

Figure 4e: Regulatory burden and unemployment

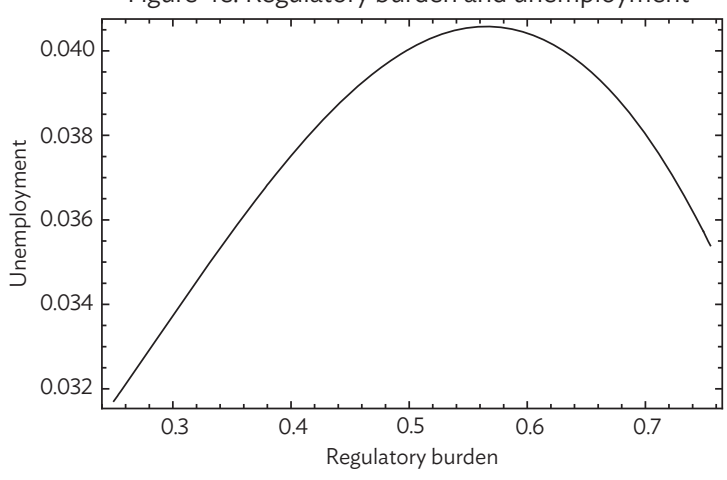

Figure 4b: Regulatory burden and share of labor force in formal sector

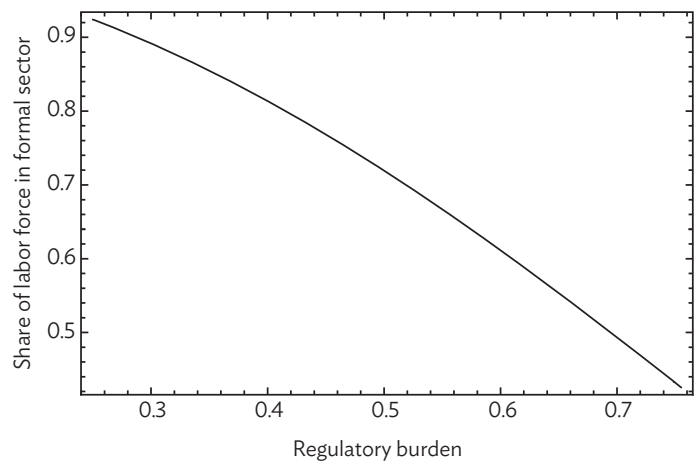

Figure 4d: Regulatory burden and job destruction

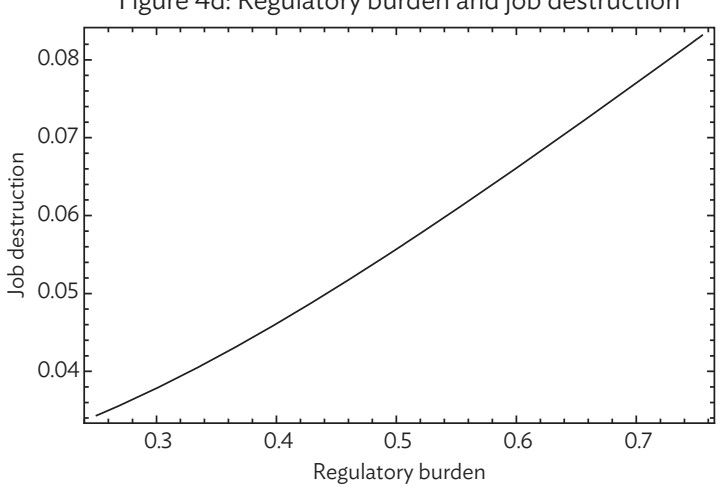

Figure 4f: Regulatory burden and unemployment

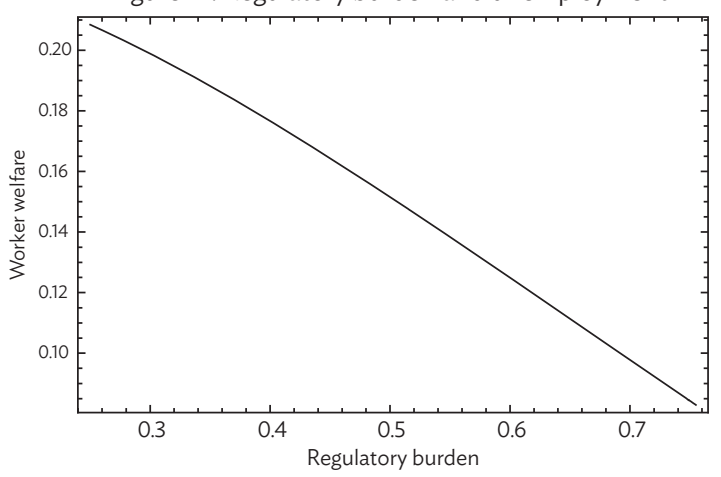

$A=8, B=1, L=1, \gamma=2 / 3, Z=.5, \rho=1, F=.75$

Source: Authors' calculations. 


\section{E. Minimum Wage Regulation}

We can also study the implications of a minimum wage regulation in the model. It must be stated at the outset that the welfare analysis becomes more complicated in this case because we already have a distortion arising from risk aversion and now we are introducing another distortion in the form of a minimum wage.

Suppose that the government imposes a binding minimum wage in the formal sector and assume that the minimum wage regulation is not binding in the informal sector. Denote the minimum wage by $\underline{w}$. Firms in the formal sector take this as given and perform the following maximization exercise:

$$
\begin{aligned}
& \operatorname{Max}_{L_{f}, \lambda_{c}}\left\{A^{\prime} \varphi^{1-\gamma}\left(\frac{1-\lambda_{c}^{2}}{2}\right)^{\gamma} L_{f}^{\gamma}-\underline{w}\left(1-\lambda_{c}\right) L_{f}\right\} \\
& \text { s.t. }\left(1-\lambda_{c}\right) U(\underline{w})+\lambda_{c} U(z) \geq U\left(w_{i}\right)
\end{aligned}
$$

The first-order conditions are ${ }^{5}$

$$
\begin{gathered}
L_{f}: A^{\prime} \varphi^{1-\gamma} \gamma\left(\frac{1-\lambda_{c}^{2}}{2}\right)^{\gamma} L_{f}^{\gamma-1}=\underline{w}\left(1-\lambda_{c}\right), \\
\lambda_{c}:-A^{\prime} \varphi^{1-\gamma} \gamma \lambda_{c}\left(\frac{1-\lambda_{c}^{2}}{2}\right)^{\gamma-1} L_{f}^{\gamma}=\rho(U(\underline{w})-U(z))-\underline{w} L_{f}
\end{gathered}
$$

The above two equations along with $\left(1-\lambda_{c}\right) U(\underline{w})+\lambda_{c} U(z)=U\left(w_{i}\right)$ determine $L_{f}, \lambda_{c}$, and $\rho$ for a given $\underline{w}$ and $w_{i}$. Essentially, $\lambda_{c}$ for all firms is given by

$$
\lambda_{c}=\frac{U(\underline{w})-U\left(w_{i}\right)}{U(\underline{w})-U(z)}
$$

The variables for the informal sector are determined as before which allow us to determine $w_{i}$ and $\varphi^{*}$ along with $\lambda_{c}$ and the share of workforce in each sector. The relevant equations are obtained simply by replacing $w_{f}$ by $w$ in equations (28)-(31) in the appendix.

5 For the above problem to make sense, it must be the case that $w>w_{i}$, that is why we assumed that the minimum wage doesn't bind in the informal sector, and therefore, it doesn't directly affect the informal sector. 
Numerical simulations shown in Figure 5 reveal that the impact of a binding minimum wage on aggregate net output is nonmonotonic as shown in Figure 5a. To understand the intuition behind this result, we need to first see the impact of a binding minimum wage on other variables of interest. A binding minimum wage leads to decreases in the share of workforce in the formal sector (Figure $5 b)$ and the share of entrepreneurs in the formal sector (Figure 5c). That is, structural transformation is impeded. Figure $5 \mathrm{~d}$ shows that a binding minimum wage leads to an increase in job destruction. Since the formal sector firms are forced to pay a higher wage, they can satisfy the reservation utility of workers by keeping the firing threshold higher. A consequence of increased job destruction combined with reduced share of workers in the formal sector is that unemployment increases first and then starts decreasing as shown in Figure 5e. The impact on worker welfare is shown in Figure $5 f$. It is not obvious from the figure but we verify that starting from no regulation of wages, a binding minimum wage initially increases worker welfare before reducing it. The reason for the initial increase in worker welfare is the general equilibrium effect of increase in demand for labor in the informal sector. However, it is soon overtaken by the negative effect due to reduced demand in the formal sector.

The most intriguing result is the nonmonotonic response of aggregate net output to increases in minimum wage shown in Figure 5 a. The intuition for this result is as follows. Since job destruction in the formal sector is suboptimally low in the decentralized equilibrium without intervention, an increase in job destruction induced by a binding minimum wage is a source of efficiency gain. However, minimum wage worsens an existing distortion which is a low share of entrepreneurs and workers in the formal sector. Recall that in the decentralized equilibrium, the share of workforce and entrepreneurs in the formal sector is lower than in the planner's problem. A binding minimum wage reduces the profit in the formal sector, and hence, the mass of entrepreneurs in the formal sector is decreasing in the minimum wage. Additionally, entrepreneurs hire fewer workers. Therefore, both the share of entrepreneurs and the share of workers in the formal sector decreases with minimum wage as shown in Figures $5 b$ and $5 c$. The net effect of minimum wage on aggregate output depends on the relative strengths of these opposing effects. When the minimum wage becomes just binding, the beneficial effect dominates and hence the aggregate output increases. Beyond a point, the distortionary effect starts dominating and as a result, aggregate output starts decreasing. Numerical simulations reveal that a binding minimum wage doesn't achieve production efficiency in the model. That is, as the minimum wage is increased, aggregate output starts decreasing before reaching the efficient level. Therefore, in this second-best world, minimum wage increases aggregate net output, but it is not appropriately targeted and hence fails to increase output to the efficient level.

Having discussed the theoretical results, we provide some suggestive empirical evidence. 
Figure 5: Minimum Wage and Labor Market Outcomes

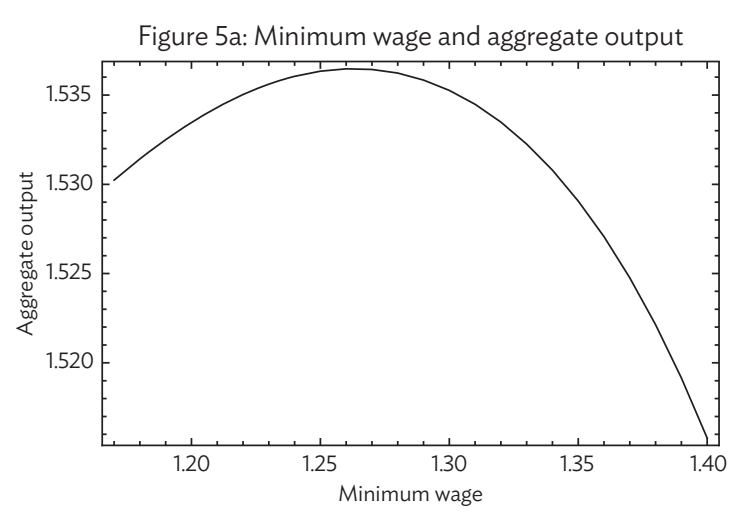

Figure 5b: Minimum wage and share of labor force

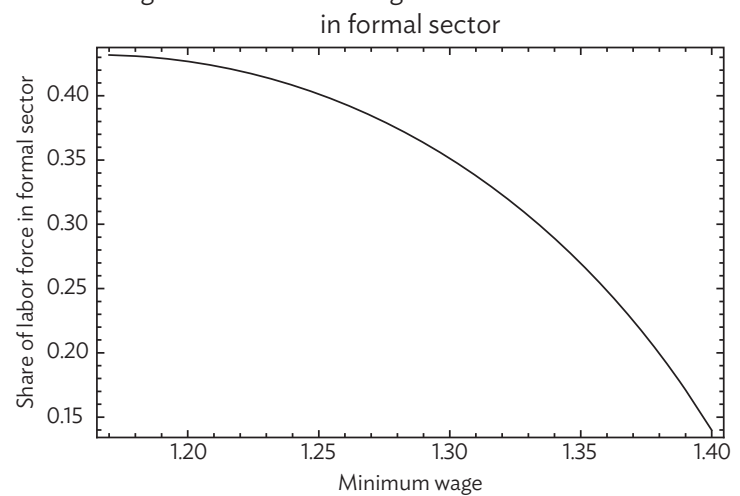

Figure 5c: Minimum wage and share of entrepreneur
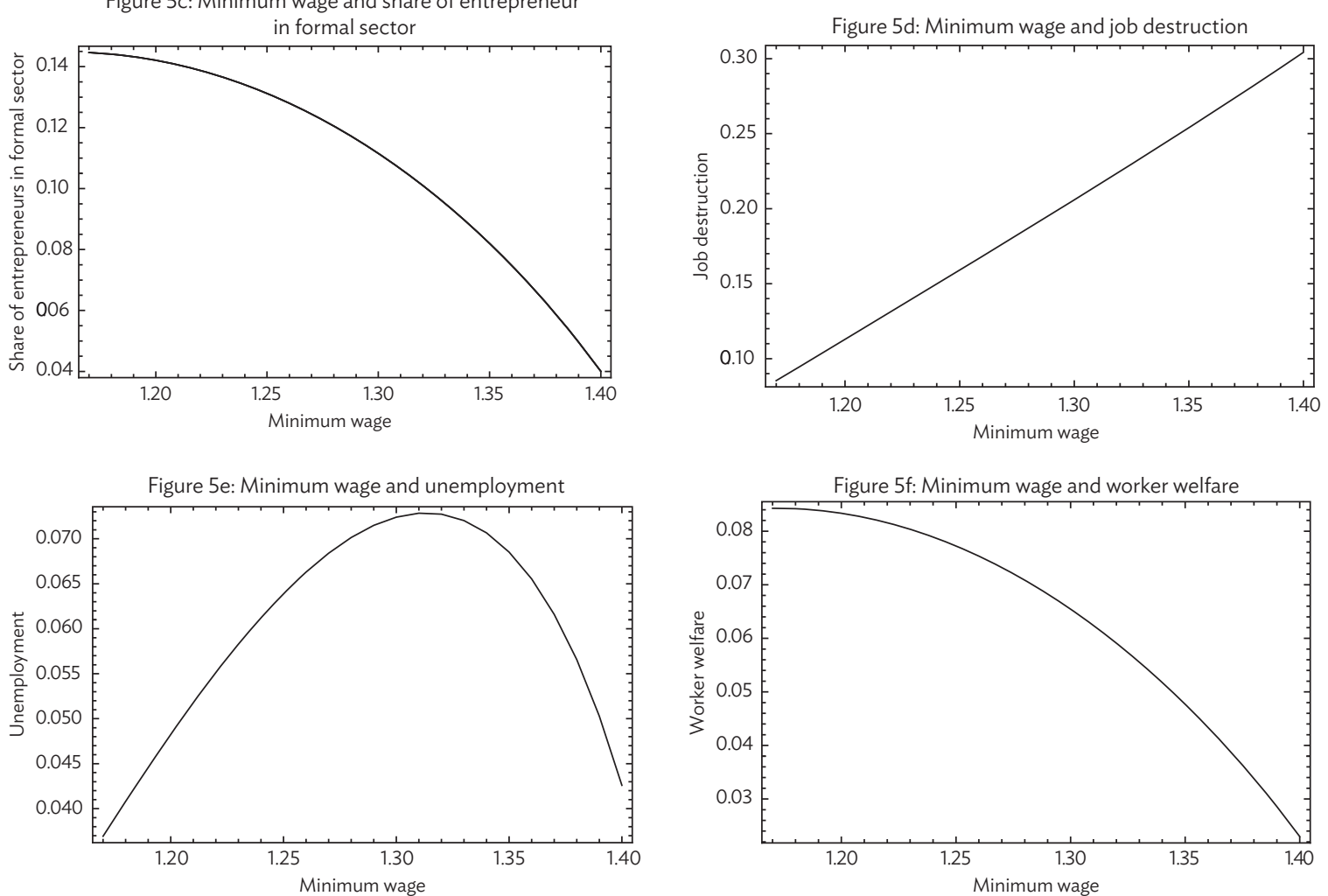

$A=8, B=1, L=1, \gamma=2 / 3, Z=.5, \rho=1, F=.75$

Source: Authors' calculations. 


\section{EMPIRICAL EXERCISE}

We now turn our attention to an empirical investigation of the relationship between the prevalence of informal employment and the three elements of labor regulations discussed in this paper, i.e., regulations that constrain firms from dismissing workers, govern severance payments, and relate to minimum wages.

We pool country-level information across six developing country regions and the years 20002014 to estimate regression equations of the following type:

$$
\text { Share_Informal }{ }_{i t}=\alpha+\beta_{1} \ln Y_{i t}+\beta_{2} \text { Labor__ }_{-} \operatorname{Reg}_{i t}+X_{i} \gamma+u_{R}+u_{t}+\varepsilon_{i t}
$$

where $i$ refers to country, $t$ refers to time, $Y$ is gross domestic product (GDP) per capita, Labor_Reg refers to one of the three elements of regulation we consider, $X$ captures various controls, $u_{R}$ and $u_{t}$ capture region and year fixed effects, respectively and $\varepsilon_{i t}$ is the error term.

Two points may be noted regarding our analysis. First, it is along the lines of Botero et al. (2004), the first cross-country study on the effects of labor regulations that covered developing countries, and the more recent work of Djankov and Ramalho (2009). However, our work differs in terms of the outcome variable of interest-a measure of informal employment in our case rather than the size of the informal sector in economic activity and other indicators (such as labor force participation and unemployment rates) in these studies. ${ }^{6}$ Additionally, our main interest is in understanding how different aspects of labor regulation affect our outcome variable. Second, the objective of our empirical analysis is simply to examine whether the predictions of the theoretical model developed in this paper match the broad patterns in cross-country data. We do not seek to establish causality. This relatively modest goal is necessitated by several factors, including the patchiness of the data available, especially on informal employment, and the lack of within-country variation in our measures of labor regulations over the relevant time periods (mostly due to the fact that regulations are often slow to change).

\section{A. Data and Variables}

\section{Share of Informal Employment}

Our measure of the share of informal employment is drawn from the ILO's KILM database. It is based on defining informal employment as the sum of own account workers and contributing family workers. This is less than ideal for two reasons. First, the measure is not available for the agricultural and nonagricultural sectors separately. The distinction is relevant for us as structural transformation typically involves a shift away from agricultural employment; since agriculture accounts for a large portion of own account and unpaid family workers, differences in the KLIM measure of informal employment over time (and across countries) may be driven more by shifts away from agriculture rather than changes or differences in the regulatory factors that are the focus of this paper. We get around this by including the share of agriculture in total employment as a control in our regressions.

6 Also, while we use actual data on informal employment, Botero et al. (2004) measure of size of informal sector is based on the opinion of experts who are asked to measure the size of the informal sector in their country. 
Second, the KILM measure excludes several categories of informal employment. These are employers in the informal sector; wage employees employed by informal sector enterprises; and wage employees employed in the formal sector, but holding "informal" jobs in terms of the employment relationship-for example, jobs that do not come under the purview of labor regulation. Employers typically represent around $0.75 \%$ to under $7 \%$ of total employment in developing countries. The other two categories omitted from the KLIM measure are harder to quantify.

Data availability is the obstacle to obtaining a more comprehensive measure of informal employment, with many developing countries' labor force surveys not distinguishing between the type of enterprise a wage employee is employed in (formal or informal sector enterprise) and lacking details on the nature of the employment relationship. For example, for the years 2000, 2005, and 2010, the number of countries with information on the share of informal employment (comprehensive definition) in nonagricultural activities was only 5, 11, and 18, respectively. The corresponding number of countries with data on informal employment defined as the sum of own account workers and contributing family workers (the KLIM measure) was 63, 71, and 78 for these years. Fortunately, both variables are strongly correlated when data are pooled for the year 2000 and beyond (correlation coefficient of 0.7).

While data from KILM covers well over 100 developed and developing countries from 1980 to 2014, there are many data gaps between years. To avoid these, we restrict our analysis to the period between 2000 and 2014 and interpolate values for missing years for countries that have at least three observations over these years. Restricting attention to developing countries which are also covered by the main database we rely on for labor regulations (see below), we are left with 53 developing countries for our analysis.

\section{Measures of Labor Regulation}

We capture regulatory restrictions on employee dismissal and the generosity of severance (or redundancy) payments using the CBR Labour Regulation Index (CBR-LRI) data set developed by the Centre for Business Research of the University of Cambridge (Adams, Bishop, and Deakin 2015). The database codes five aspects of labor regulation in 117 countries over the period from the 1970s to the present day. Each of the five are themselves based on 40 subcomponents of regulation.

We focus on the "regulation of dismissal" aspect of labor regulation, itself composed of nine distinct subcomponents. One of the subcomponents is a measure of legally mandated redundancy compensation, which is the amount of compensation payable to a worker made redundant after 3 years of employment, expressed in weeks of pay. The variable is normalized such that 0 weeks of pay is assigned a value of 0 and 12 weeks of pay is assigned a value of 1 . We use this variable as our measure of generosity of severance pay, or redundancy compensation.

Next, we average the remaining eight variables to construct a measure of the severity of dismissal regulations purged of rules on severance/redundancy pay. Like the measure of generosity of severance pay, higher values of the residual measure of dismissal regulations are more proworker. Given the country and year coverage of our dependent variable, the two measures used from the CBRLRI data set cover 53 countries over 2000-2014. 
To examine the effect of minimum wages on informal employment, we compute the ratio of minimum wages to GDP per capita. Like our other two measures of labor regulation, higher values of this ratio represent a more proworker regulatory regime. Our source of cross-country information on (monthly) minimum wages is the ILO STAT database. The database excludes minimum wages determined by collective bargaining. In cases where the minimum wages differ across subnational regions, either the minimum wage for the capital city or an average of regional wages is used. For countries that mandate minimum wages by sector, the minimum wage for manufacturing or unskilled labor is applied. We compute the ratio by first converting the monthly minimum wage data from ILO STAT, expressed in current local currency, into current US dollars using market exchange rates from the World Bank World Development Indicators. These are divided by 1/12th of GDP per capita to arrive at the ratio of the monthly minimum wage to GDP per capita. This ratio is computed for 56 developing countries from 2000 to 2013.

\section{Other Variables}

Aside from GDP per capita and the share of agriculture in total employment (Agrishare), both of which are from the World Development Indicators database, respectively, we also include as controls measures of the ease of paying taxes and access to credit provided in the World Bank's Doing Business (DB) database. Both the tax regime as well as access to credit are widely believed to influence firms' decision to formalize or not (see, for example, the work of Djankov et al. 2008). Controlling for these is, therefore, important, especially as countries with relatively flexible labor regulations are likely to have a general regulatory environment that is business friendly. We do so by using the DB database's country-specific "distance to frontier" measure for the ease of paying taxes and access to credit variables, and for which lower values represent better regulatory environments. We use the average of the distance to frontier values per country across DB years to allow for better coverage when estimating equation (27). This is not too much of a loss as much of the variation in these measures appears across countries rather than over time for the period we consider.

Finally, we control for enforcement of regulation in some of our analysis. We experiment with two measures of enforcement, namely: (i) the number of labor inspectors per 10,000 employed persons, sourced from the ILOSTAT database and available for 26 developing countries and various years between 2009 to 2014; and (ii) the rule of law index from the World Bank's World Governance Indicators, which is available for 2000, 2002-2015 for 215 countries and measures the confidence of agents in the rules of society, the quality of contract enforcement, property rights, the police, the courts, and the likelihood of crime and violence. Higher values represent greater adherence to the rule of law.

The relationship between these measures of enforcement and informal employment may well differ; it is also likely to be complex. For example, a larger number of inspectors is likely to imply greater enforcement of labor regulations; if labor regulations impose constraints on the formalization process, then greater enforcement would be associated with greater informal employment. On the other hand, the other two enforcement measures capture more qualitative aspects of regulatory institutions. Higher scores on these are likely to be associated with regulatory systems that are conducive to formalization and a decline in informal employment. 
Table 1: Summary Statistics

\begin{tabular}{|c|c|c|c|c|c|c|c|}
\hline Region & $\begin{array}{c}\text { Share of Own } \\
\text { Account and } \\
\text { Contributing } \\
\text { Family } \\
\text { Workers } \\
\end{array}$ & $\begin{array}{l}\text { Dismissal } \\
\text { Regulations } \\
\text { as Defined in } \\
\text { the Text }\end{array}$ & $\begin{array}{l}\text { Redundancy } \\
\text { Compensation }\end{array}$ & $\begin{array}{c}\text { Minimum } \\
\text { Wage to GDP } \\
\text { per Capita } \\
\text { Ratio (\%) }\end{array}$ & $\begin{array}{l}\text { GDP per } \\
\text { Capita } \\
\text { (real USD) }\end{array}$ & $\begin{array}{c}\text { Number of } \\
\text { Countries }\end{array}$ & $\begin{array}{c}\text { Years } \\
\text { Covered }\end{array}$ \\
\hline All regions & $\begin{array}{c}43.05 \\
(22.44)\end{array}$ & $\begin{array}{c}0.51 \\
(0.16)\end{array}$ & $\begin{array}{c}0.66 \\
(0.35)\end{array}$ & $\begin{array}{c}54.95 \\
(44.73)\end{array}$ & $\begin{array}{c}2,950.91 \\
(2,340.82)\end{array}$ & $\begin{array}{l}53 \text { (47 for } \\
\text { minimum wage) }\end{array}$ & $\begin{array}{l}2000-2014 \\
\text { (2013 for } \\
\text { minimum wage) }\end{array}$ \\
\hline $\begin{array}{l}\text { East Asia } \\
\text { and the } \\
\text { Pacific }\end{array}$ & $\begin{array}{l}54.64 \\
(18.56)\end{array}$ & $\begin{array}{r}0.53 \\
(0.15)\end{array}$ & $\begin{array}{c}0.72 \\
(0.34)\end{array}$ & $\begin{array}{c}55.15 \\
(48.37)\end{array}$ & $\begin{array}{l}2,058.63 \\
(1,865.33)\end{array}$ & 7 & $\begin{array}{l}2000-2014 \\
\text { ( } 2013 \text { for } \\
\text { minimum wage) }\end{array}$ \\
\hline $\begin{array}{l}\text { Europe and } \\
\text { Central Asia }\end{array}$ & $\begin{array}{l}29.25 \\
(18.10)\end{array}$ & $\begin{array}{c}0.54 \\
(0.33)\end{array}$ & $\begin{array}{r}0.54 \\
(0.11)\end{array}$ & $\begin{array}{l}26.19 \\
(16.34)\end{array}$ & $\begin{array}{c}4,366.95 \\
(2,868.58)\end{array}$ & $\begin{array}{l}13 \text { (12 for } \\
\text { minimum wage) }\end{array}$ & $\begin{array}{l}2000-2014 \\
\text { ( } 2013 \text { for } \\
\text { minimum wage) }\end{array}$ \\
\hline $\begin{array}{l}\text { Latin } \\
\text { America }\end{array}$ & $\begin{array}{l}38.71 \\
(11.61)\end{array}$ & $\begin{array}{c}0.41 \\
(0.17)\end{array}$ & $\begin{array}{c}0.86 \\
(0.22)\end{array}$ & $\begin{array}{c}61.43 \\
(29.65)\end{array}$ & $\begin{array}{l}3,729.53 \\
(1,862.95)\end{array}$ & $\begin{array}{l}13 \text { (12 for } \\
\text { minimum wage) }\end{array}$ & $\begin{array}{l}2000-2014 \\
\text { ( } 2013 \text { for } \\
\text { minimum wage) }\end{array}$ \\
\hline $\begin{array}{l}\text { Middle East } \\
\text { and North } \\
\text { Africa }\end{array}$ & $\begin{array}{l}29.54 \\
(14.90)\end{array}$ & $\begin{array}{r}0.63 \\
(0.11)\end{array}$ & $\begin{array}{c}0.74 \\
(0.34)\end{array}$ & $\begin{array}{l}80.72 \\
(73.69)\end{array}$ & $\begin{array}{l}2,396.41 \\
(849.97)\end{array}$ & $\begin{array}{l}7 \text { ( } 6 \text { for } \\
\text { minimum wage) }\end{array}$ & 2000-2013 \\
\hline South Asia & $\begin{array}{l}63.40 \\
(17.49)\end{array}$ & $\begin{array}{r}0.63 \\
(0.13)\end{array}$ & $\begin{array}{l}0.67 \\
(0.32)\end{array}$ & $\begin{array}{l}58.00 \\
(21.67)\end{array}$ & $\begin{array}{l}875.26 \\
(412.61)\end{array}$ & 4 & $\begin{array}{l}2000-2013 \\
\text { ( } 2011 \text { for } \\
\text { minimum wage) }\end{array}$ \\
\hline $\begin{array}{l}\text { Sub- } \\
\text { Saharan } \\
\text { Africa }\end{array}$ & $\begin{array}{c}61.50 \\
(27.84)\end{array}$ & $\begin{array}{c}0.47 \\
(0.12)\end{array}$ & $\begin{array}{c}0.34 \\
(0.32)\end{array}$ & $\begin{array}{l}72.45 \\
(51.76)\end{array}$ & $\begin{array}{c}1,582.01 \\
(1,895.09)\end{array}$ & $\begin{array}{l}9 \text { ( } 6 \text { for } \\
\text { minimum wage) }\end{array}$ & 2000-2013 \\
\hline
\end{tabular}

GDP = gross domestic product, USD = United States dollar.

Note: Figures represent average values for all available years (with standard deviation in parenthesis).

Source: Authors' estimates based on CBRLRI database (accessed 5 January 2016); ILO KILM.

http://www.ilo.org/ilostat/faces/wcnav_defaultSelection?_afrLoop=246699509158316\&_afrWindowMode=0\&_afrWindowld=null\#!\%40\%40\% 3F_afrWindowld\%3Dnull\%26_afrLoop\%3D246699509158316\%26_afrWindowMode\%3D0\%26_adf.ctrl-state\%3Dg2madkays_45 (accessed 5 March 2016); and World Development Indicators databases. https://data.worldbank.org/data-catalog/world-development-indicators (accessed 1 June 2016).

Table 1 provides summary statistics for the main variables of interest-the share of informal employment based on the KLIM measure and the three elements of labor regulation-plus GDP per capita. There is considerable variation in the prevalence of informal employment across the developing world, with shares largest in South Asia and Sub-Saharan Africa (around 55\%) and lowest in developing countries in Europe and Central Asia (around 16\%) over the period considered. As for labor regulations, Latin America and South Asia tend to have greater restrictions on dismissal and more generous severance pay. Minimum wages tend to be higher relative to GDP per capita in Middle East and North Africa and Sub-Saharan Africa.

As one would expect, a simple scatterplot of the KLIM measure of informal employment and GDP per capita shows a strong inverse relationship between the two variables (first panel of Figure 6). That is, informality declines as we observe countries at higher levels of development. We also plot the share of informal employment against our measures of labor regulations (remaining panels, Figure 6). To varying degrees, all three measures appear to be positively correlated with informality, though the relationship appears weakest for redundancy compensation. 
Figure 6: Scatter Plots: Share of Informal Employment (own account workers)

A. Log of GDP per capita

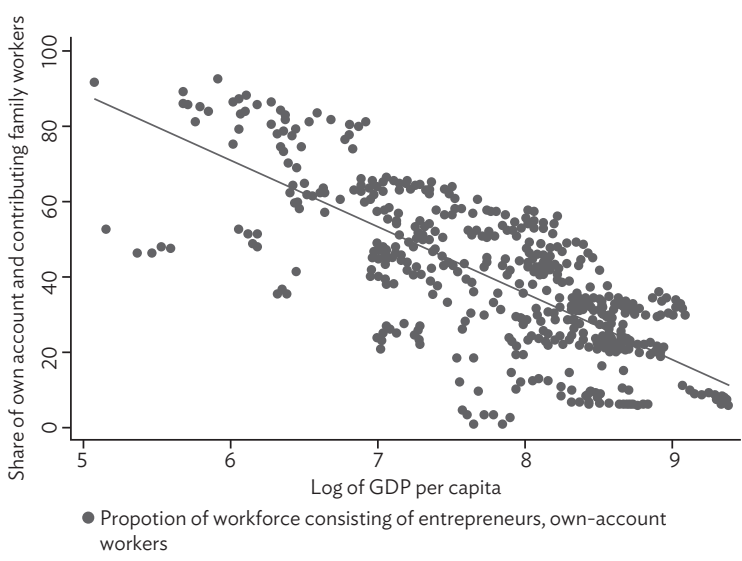

C. Redundancy compensation*

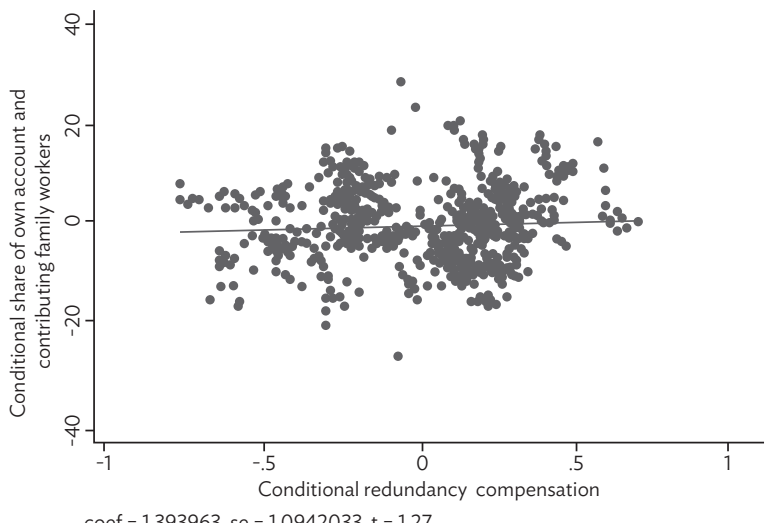

B. Dismissal regulations*

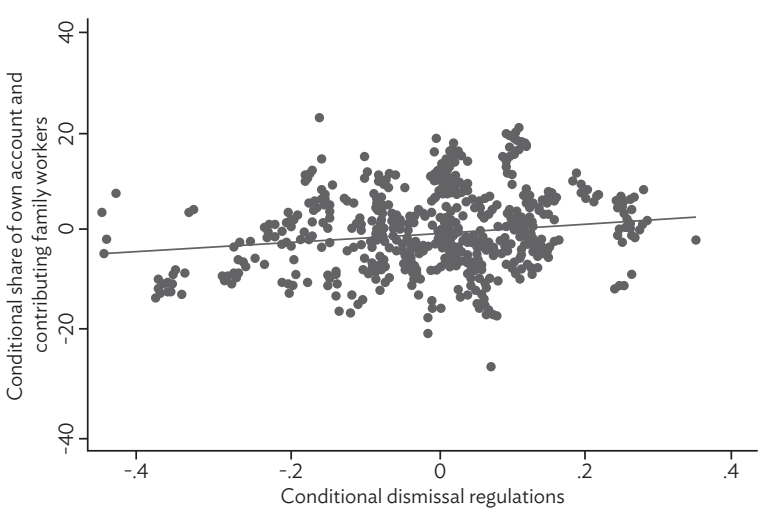

coef $=9.5120825$, se $=2.3699082, t=4.01$

D. Minimum wage-to-GDP ratio*

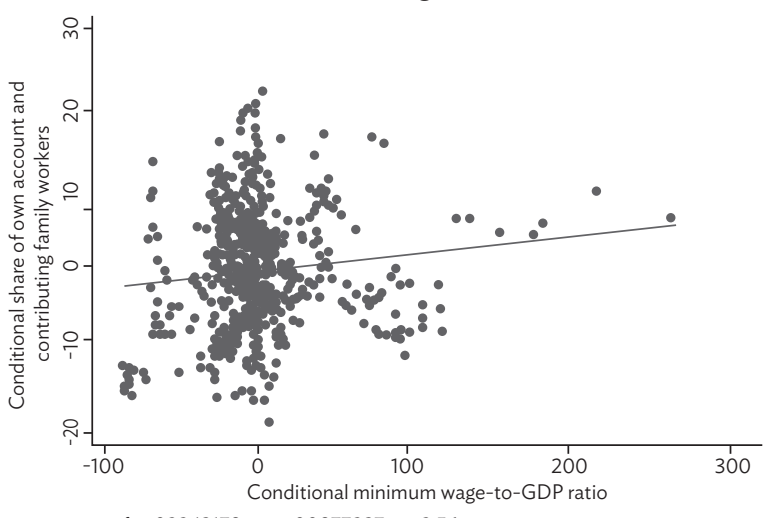

coef $=.02243178, \mathrm{se}=.00877237, \mathrm{t}=2.56$

Note: ${ }^{*}$ The residual of labor regulation measure is graphed with the residual of informal employment share after taking out the effect of log of gross domestic product (GDP) per capita with the slope corresponding to estimates between labor regulation measure and informal employment share in model (27) using the base specification in Table 2 (dismissal regulation), Table 3 (redundancy compensation), and Table 4 (minimum wage-to-GDP ratio).

Source: Authors' estimates based on CBRLRI database (accessed 5 January 2016); ILO KILM.

http://www.ilo.org/ilostat/faces/wcnav_defaultSelection?_afrLoop=246699509158316\&_afrWindowMode=0\&_afrWindowld=null\#!\%40\% 40\%3F_afrWindowld\%3Dnull\%26_afrLoop\%3D246699509158316\%26_afrWindowMode\%3D0\%26_adf.ctrl-state\%3Dg2madkays_45 (accessed 5 March 2016); and World Development Indicators databases. https://data.worldbank.org/data-catalog/world-developmentindicators (accessed 1 June 2016).

\section{B. Results}

We perform three separate regressions to isolate the effect of the two regulations and minimum wages on the share of informal employment. GDP per capita and the share of agriculture in total employment are introduced as controls in all specifications. We begin with a baseline specification and then add more controls. A first set of these additional controls pertain to the regulatory environment (access to credit and paying taxes from the World Bank's Doing Business database), and the second pertains to measures of enforcement and rule of law. 
The positively and significantly estimated coefficient on the index of dismissal regulations in column 1 of Table 2 implies that tougher dismissal laws are associated with a higher share of informal employment. Adding controls for the business environment by introducing "distance to frontier" measures for access to credit and the tax regime, widely believed to be important determinants of informality, does not alter the positive association between tougher dismissal laws and the share of informal employment (columns 2 and 3). (Interestingly, the estimated coefficient of only the tax regime is positively signed, suggesting that in our sample, at least, and with controls for incomes and agricultural employment included, a weaker tax regime but not weaker access to credit is associated with greater informal employment. $)^{7}$

Since enforcement regimes can vary considerably, it is useful to control for these, something done in the specifications reported in columns 4 and 5. A direct measure of enforcement of labor regulations - the number of labor inspectors per 10,000 employees-is available for only 22 of our sample 53 countries. Nevertheless, the results are interesting. While the dismissal regulation variable on its own is statistically insignificant (and negatively signed), its interaction with the inspection rate is positive and significant (column 4), suggesting that in countries with stricter enforcement of labor regulation, tougher dismissal regulations have a bite and dampen the creation of formal employment opportunities. Thus, consider the 25th and 75th percentile values of the inspection rate across the 73 observations used in generating column 4. These values are 0.3 and 0.6 , respectively. While the former (the average value for Brazil) implies that a 0.1 point increase in the strength of dismissal regulation leads to an increase of 1.1 percentage points in the share of informal employment, the latter (the average value for Sri Lanka) implies an increase of 3.2 percentage points in the share of informal employment. Stricter inspection itself is negatively associated with informal employment. These findings are repeated qualitatively, and with greater force, in column 5 where the inspection rate variable is substituted with the rule of law index. Here, dismissal regulation is associated with greater informal employment both on its own as well as in countries with a stronger rule of law.

Switching from dismissal regulation to severance pay changes results dramatically (Table 3). In no specification is having a more generous redundancy compensation associated with greater informal employment. In the only case where a term involving redundancy compensation appears with a statistically significant effect-in interaction with the rule of law in column 5-the estimated coefficient is negatively signed. The negative coefficient of the interaction term suggests that in countries with a stronger rule of law a stronger redundancy compensation lowers informal employment.

7 Recall that a low value of these variables captures better regulatory environment. Therefore, a positive association between informal employment and ease of paying taxes implies that better regulatory environment is positively associated with formal employment, a result consistent with the impact of regulatory burden on formal employment discussed in the theoretical model. 
Table 2: Regression Results, Dismissal Regulations

\begin{tabular}{|c|c|c|c|c|c|}
\hline \multirow[b]{2}{*}{$\begin{array}{l}\text { Share of Own Account } \\
\text { Workers }\end{array}$} & \multirow[b]{2}{*}{$\begin{array}{c}\text { Base } \\
\text { Specification } \\
\text { (1) }\end{array}$} & \multicolumn{2}{|c|}{$\begin{array}{l}\text { Regulatory Environment } \\
\text { (distance to frontier controls) }\end{array}$} & \multicolumn{2}{|c|}{ Enforcement Regime } \\
\hline & & $\begin{array}{l}\text { Access to Credit } \\
\text { (2) }\end{array}$ & $\begin{array}{c}\text { Ease of Paying } \\
\text { Taxes } \\
\text { (3) }\end{array}$ & $\begin{array}{c}\text { Inspection Rate } \\
(4)\end{array}$ & $\begin{array}{l}\text { Rule of Law } \\
\text { (5) }\end{array}$ \\
\hline $\begin{array}{l}\text { In GDP per capita } \\
\text { (real USD) }\end{array}$ & $\begin{array}{r}-5.16^{* * *} \\
(0.62)\end{array}$ & $\begin{array}{r}-4.71^{* * *} \\
(0.65)\end{array}$ & $\begin{array}{r}-5.30^{* * *} \\
(0.61)\end{array}$ & $\begin{array}{r}5.23^{* * *} \\
(2.55)\end{array}$ & $\begin{array}{r}-4.58^{* * *} \\
(0.71)\end{array}$ \\
\hline Dismissal regulations & $\begin{array}{l}9.51^{* * *} \\
(2.37)\end{array}$ & $\begin{array}{r}10.58^{* * *} \\
(2.42)\end{array}$ & $\begin{array}{r}11.34^{* * *} \\
(2.43)\end{array}$ & $\begin{array}{r}-9.53 \\
(12.29)\end{array}$ & $\begin{array}{r}8.85^{* * *} \\
(2.82)\end{array}$ \\
\hline $\begin{array}{l}\text { Share of employment } \\
\text { in agriculture }\end{array}$ & $\begin{array}{l}0.87^{* * *} \\
(0.03)\end{array}$ & $\begin{array}{l}0.87^{* * *} \\
(0.03)\end{array}$ & $\begin{array}{l}0.88^{* * *} \\
(0.03)\end{array}$ & $\begin{array}{l}1.18^{* * *} \\
(0.14)\end{array}$ & $\begin{array}{l}0.84^{* * *} \\
(0.03)\end{array}$ \\
\hline Access to credit & & $\begin{array}{r}-0.05^{* * *} \\
(0.02)\end{array}$ & & & \\
\hline Ease of paying taxes & & & $\begin{array}{l}0.08^{* * *} \\
(0.03)\end{array}$ & & \\
\hline Inspection rate & & & & $\begin{array}{r}-48.14^{* * *} \\
(15.88)\end{array}$ & \\
\hline $\begin{array}{l}\text { Inspection rate } \mathrm{x} \\
\text { Dismissal regulations }\end{array}$ & & & & $\begin{array}{r}69.76^{* * *} \\
(25.93)\end{array}$ & \\
\hline Rule of law index & & & & & $\begin{array}{r}-9.94^{* * *} \\
(2.54)\end{array}$ \\
\hline $\begin{array}{l}\text { Rule of law index } x \\
\text { Dismissal regulations }\end{array}$ & & & & & $\begin{array}{r}14.21^{* * *} \\
(4.51)\end{array}$ \\
\hline East Asia and the Pacific & $\begin{array}{r}-7.12^{* * *} \\
(1.16)\end{array}$ & $\begin{array}{r}-6.82^{* * *} \\
(1.16)\end{array}$ & $\begin{array}{r}-8.92^{* * *} \\
(1.30)\end{array}$ & $\begin{array}{r}-13.37^{* * *} \\
(3.26)\end{array}$ & $\begin{array}{r}-4.71^{* * *} \\
(1.39)\end{array}$ \\
\hline Europe and Central Asia & $\begin{array}{r}-14.99^{* * *} \\
(0.99)\end{array}$ & $\begin{array}{r}-14.80^{* * *} \\
(0.99)\end{array}$ & $\begin{array}{r}-16.52^{* * *} \\
(1.11)\end{array}$ & $\begin{array}{r}-12.58^{* * *} \\
(2.67)\end{array}$ & $\begin{array}{r}-14.01^{* * *} \\
(1.09)\end{array}$ \\
\hline $\begin{array}{l}\text { Latin America and the } \\
\text { Caribbean }\end{array}$ & - & - & - & - & - \\
\hline $\begin{array}{l}\text { Middle East and North } \\
\text { Africa }\end{array}$ & $\begin{array}{r}-15.18^{* * *} \\
(1.28)\end{array}$ & $\begin{array}{r}-16.60^{* * *} \\
(1.44)\end{array}$ & $\begin{array}{r}-16.71^{* * *} \\
(1.37)\end{array}$ & $\begin{array}{r}-15.58^{* * *} \\
(5.67)\end{array}$ & $\begin{array}{r}-12.71^{* * *} \\
(1.53)\end{array}$ \\
\hline South Asia & $\begin{array}{r}-5.55^{* * *} \\
(1.58)\end{array}$ & $\begin{array}{r}-5.44^{* * *} \\
(1.58)\end{array}$ & $\begin{array}{r}-6.44^{* * *} \\
(1.60)\end{array}$ & $\begin{array}{l}-5.20 \\
(4.52)\end{array}$ & $\begin{array}{l}-2.67 \\
(1.90)\end{array}$ \\
\hline Sub-Saharan Africa & $\begin{array}{r}-11.59^{* * *} \\
(1.27)\end{array}$ & $\begin{array}{r}-11.06^{* * *} \\
(1.45)\end{array}$ & $\begin{array}{r}-13.69^{* *} \\
(1.45)\end{array}$ & $\begin{array}{r}-10.86^{* *} \\
(4.24)\end{array}$ & $\begin{array}{r}-9.75^{* * *} \\
(1.49)\end{array}$ \\
\hline Constant & $\begin{array}{r}56.87^{* * *} \\
(5.70)\end{array}$ & $\begin{array}{r}55.67^{* * *} \\
(5.71)\end{array}$ & $\begin{array}{r}53.52^{* * *} \\
(5.77)\end{array}$ & $\begin{array}{r}-16.57 \\
(25.52)\end{array}$ & $\begin{array}{r}51.27^{* * *} \\
(6.39)\end{array}$ \\
\hline Year dummies & Yes & Yes & Yes & Yes & Yes \\
\hline Observations & 595 & 595 & 595 & 73 & 545 \\
\hline R-squared & 0.88 & 0.88 & 0.88 & 0.83 & 0.88 \\
\hline Number of countries & 53 & 53 & 53 & 22 & 51 \\
\hline
\end{tabular}

USD = United States dollar.

Notes: Standard errors in parentheses; ${ }^{* * *} p<001,{ }^{* *} p<0.05,{ }^{*} p<0.1$.

Source: Authors' estimates based on CBRLRI database (accessed 5 January 2016); ILO KILM.

http://www.ilo.org/ilostat/faces/wcnav_defaultSelection?_afrLoop=246699509158316\&_afrWindowMode=0\&_afrWindowld=null\#!\%40\%40

\%3F_afrWindowld\%3Dnull\%26_afrLoop\%3D246699509158316\%26_afrWindowMode\%3D0\%26_adf.ctrl-state\%3Dg2madkays_45

(accessed 5 March 2016); World Development Indicators databases. https://data.worldbank.org/data-catalog/world-development-indicators (accessed 1 June 2016); and World Governance Indicators. http://info.worldbank.org/governance/wgi/\#home_(accessed 1 June 2016). 


\section{Table 3: Regression Results, Redundancy Compensation}

\begin{tabular}{|c|c|c|c|c|c|}
\hline \multirow[b]{2}{*}{ Share of Own Account Workers } & \multirow[b]{2}{*}{$\begin{array}{c}\text { Base } \\
\text { Specification } \\
\text { (1) }\end{array}$} & \multicolumn{2}{|c|}{$\begin{array}{l}\text { Regulatory Environment } \\
\text { (distance to frontier controls) }\end{array}$} & \multicolumn{2}{|c|}{ Enforcement Regime } \\
\hline & & $\begin{array}{l}\text { Access to Credit } \\
\text { (2) }\end{array}$ & $\begin{array}{c}\text { Ease of Paying } \\
\text { Taxes } \\
\text { (3) }\end{array}$ & $\begin{array}{l}\text { Inspection Rate } \\
\text { (4) }\end{array}$ & $\begin{array}{l}\text { Rule of Law } \\
\text { (5) }\end{array}$ \\
\hline In GDP per capita (real USD) & $-5.29^{* * *}$ & $-5.11^{* * *}$ & $-5.39^{* * *}$ & 4.91 & $-4.69^{* * *}$ \\
\hline & $(0.62)$ & $(0.65)$ & $(0.63)$ & $(3.28)$ & $(0.71)$ \\
\hline Redundancy compensation & $\begin{array}{r}1.39 \\
(1.09)\end{array}$ & $\begin{array}{r}1.18 \\
(1.12)\end{array}$ & $\begin{array}{r}1.46 \\
(1.09)\end{array}$ & $\begin{array}{r}2.01 \\
(5.69)\end{array}$ & $\begin{array}{r}-1.17 \\
(1.42)\end{array}$ \\
\hline Share of employment in agriculture & $\begin{array}{l}0.86^{* * *} \\
(0.03)\end{array}$ & $\begin{array}{l}0.87^{* * *} \\
(0.03)\end{array}$ & $\begin{array}{l}0.87^{* * *} \\
(0.03)\end{array}$ & $\begin{array}{r}1.28^{* * *} \\
(0.17)\end{array}$ & $\begin{array}{l}0.86^{* * *} \\
(0.03)\end{array}$ \\
\hline Access to credit & & $\begin{array}{l}-0.02 \\
(0.02)\end{array}$ & & & \\
\hline Ease of paying taxes & & & $\begin{array}{r}0.05^{*} \\
(0.03)\end{array}$ & & \\
\hline Inspection rate & & & & $\begin{array}{l}-4.00 \\
(3.55)\end{array}$ & \\
\hline $\begin{array}{l}\text { Inspection rate } x \text { Redundancy } \\
\text { compensation }\end{array}$ & & & & $\begin{array}{l}-4.38 \\
(7.20)\end{array}$ & \\
\hline Rule of law index & & & & & $\begin{array}{r}0.90 \\
(1.45)\end{array}$ \\
\hline $\begin{array}{l}\text { Rule of law index } x \text { Redundancy } \\
\text { compensation }\end{array}$ & & & & & $\begin{array}{r}-6.22^{* * *} \\
(1.83)\end{array}$ \\
\hline East Asia and the Pacific & $\begin{array}{r}-5.73^{* * *} \\
(1.16)\end{array}$ & $\begin{array}{r}-5.58^{* * *} \\
(1.17)\end{array}$ & $\begin{array}{r}-6.69^{* * *} \\
(1.27)\end{array}$ & $\begin{array}{r}-11.84^{* * *} \\
(3.89)\end{array}$ & $\begin{array}{r}-4.10^{* * *} \\
(1.30)\end{array}$ \\
\hline Europe and Central Asia & $\begin{array}{r}-13.12^{* * *} \\
(1.00)\end{array}$ & $\begin{array}{r}-13.03^{* * *} \\
(1.01)\end{array}$ & $\begin{array}{r}-13.87^{* * *} \\
(1.08)\end{array}$ & $\begin{array}{r}-11.28^{* * *} \\
(2.93)\end{array}$ & $\begin{array}{r}-13.10^{* * *} \\
(1.04)\end{array}$ \\
\hline Latin America and the Caribbean & - & - & - & - & - \\
\hline Middle East and North Africa & $\begin{array}{r}-12.96^{* * *} \\
(1.20)\end{array}$ & $\begin{array}{r}-13.54^{* * *} \\
(1.35)\end{array}$ & $\begin{array}{r}-13.65^{* * *} \\
(1.26)\end{array}$ & $\begin{array}{r}-10.88 \\
(6.66)\end{array}$ & $\begin{array}{r}-10.30^{* * *} \\
(1.33)\end{array}$ \\
\hline South Asia & $\begin{array}{r}-3.16^{* *} \\
(1.54)\end{array}$ & $\begin{array}{r}-3.06^{* *} \\
(1.55)\end{array}$ & $\begin{array}{r}-3.45^{* *} \\
(1.55)\end{array}$ & $\begin{array}{l}-6.45 \\
(5.26)\end{array}$ & $\begin{array}{l}-1.45 \\
(1.73)\end{array}$ \\
\hline Sub-Saharan Africa & $\begin{array}{r}-10.42^{* * *} \\
(1.44)\end{array}$ & $\begin{array}{r}-10.29^{* * *} \\
(1.44)\end{array}$ & $\begin{array}{r}-11.63^{* * *} \\
(1.58)\end{array}$ & $\begin{array}{r}-9.53^{*} \\
(5.11)\end{array}$ & $\begin{array}{r}-8.31^{* * *} \\
(1.58)\end{array}$ \\
\hline Constant & $\begin{array}{r}60.49^{* * *} \\
(5.79)\end{array}$ & $\begin{array}{r}60.51^{* * *} \\
(5.79)\end{array}$ & $\begin{array}{r}58.99^{* * *} \\
(5.84)\end{array}$ & $\begin{array}{l}-25.88 \\
(28.44)\end{array}$ & $\begin{array}{r}55.38^{* * *} \\
(6.52)\end{array}$ \\
\hline Year dummies & Yes & Yes & Yes & Yes & Yes \\
\hline Observations & 595 & 595 & 595 & 73 & 545 \\
\hline R-squared & 0.88 & 0.88 & 0.88 & 0.77 & 0.88 \\
\hline Number of countries & 53 & 53 & 53 & 22 & 51 \\
\hline
\end{tabular}

GDP = gross domestic product, USD = United States dollar.

Notes: Standard errors in parentheses; ${ }^{* *} p<001,{ }^{* *} p<0.05,{ }^{*} p<0.1$.

Source: Authors' estimates based on CBRLRI database (accessed 5 January 2016); ILO KILM.

http://www.ilo.org/ilostat/faces/wcnav_defaultSelection?_afrLoop=246699509158316\&_afrWindowMode=0\&_afrWindowld=null\#!\%40\% 40\%3F_afrWindowld\%3Dnull\%26_afrLoop\%3D246699509158316\%26_afrWindowMode\%3D0\%26_adf.ctrl-state\%3Dg2madkays_45 (accessed 5 March 2016); World Development Indicators databases. https://data.worldbank.org/data-catalog/world-developmentindicators (accessed 1 June 2016); and World Governance Indicators. http://info.worldbank.org/governance/wgi/\#home_(accessed 1 June 2016). 
Table 4: Regression Results, Minimum Wage to GDP Ratio

\begin{tabular}{|c|c|c|c|c|c|}
\hline \multirow[b]{2}{*}{ Share of Own Account Workers } & \multirow[b]{2}{*}{$\begin{array}{c}\text { Base } \\
\text { Specification } \\
(1)\end{array}$} & \multicolumn{2}{|c|}{$\begin{array}{c}\text { Regulatory Environment } \\
\text { (distance to frontier controls) }\end{array}$} & \multicolumn{2}{|c|}{ Enforcement Regime } \\
\hline & & $\begin{array}{l}\text { Access to Credit } \\
\text { (2) }\end{array}$ & $\begin{array}{l}\text { Ease of Paying } \\
\text { Taxes } \\
\text { (3) }\end{array}$ & $\begin{array}{l}\text { Inspection Rate } \\
\text { (4) }\end{array}$ & $\begin{array}{l}\text { Rule of Law } \\
\text { (5) }\end{array}$ \\
\hline In GDP per capita (real USD) & $\begin{array}{r}-3.75^{* * *} \\
(0.70)\end{array}$ & $\begin{array}{r}-3.71^{* * *} \\
(0.72)\end{array}$ & $\begin{array}{r}-3.83^{* * *} \\
(0.70)\end{array}$ & $\begin{array}{r}4.55 \\
(3.08)\end{array}$ & $\begin{array}{r}-2.49^{* * *} \\
(0.79)\end{array}$ \\
\hline Minwage to GDP ratio & $\begin{array}{l}0.02^{* *} \\
(0.01)\end{array}$ & $\begin{array}{l}0.02^{* *} \\
(0.01)\end{array}$ & $\begin{array}{l}0.02^{* *} \\
(0.01)\end{array}$ & $\begin{array}{r}0.03 \\
(0.06)\end{array}$ & $\begin{array}{r}0.08^{* * *} \\
(0.02)\end{array}$ \\
\hline $\begin{array}{l}\text { Share of employment in agriculture } \\
\text { Access to credit }\end{array}$ & $\begin{array}{c}0.89^{* * *} \\
(0.03)\end{array}$ & $\begin{array}{r}0.89^{* * *} \\
(0.03) \\
-0.01\end{array}$ & $\begin{array}{l}0.89^{* * *} \\
(0.03)\end{array}$ & $\begin{array}{r}1.28^{* * *} \\
(0.15)\end{array}$ & $\begin{array}{r}0.87^{* * *} \\
(0.03)\end{array}$ \\
\hline Ease of paying taxes & & $(0.03)$ & $\begin{array}{r}0.04 \\
(0.03)\end{array}$ & & \\
\hline Inspection rate & & & & $\begin{array}{l}11.43^{*} \\
(6.66)\end{array}$ & \\
\hline $\begin{array}{l}\text { Inspection rate } \times \text { Minwage } \\
\text { to GDP ratio }\end{array}$ & & & & $\begin{array}{r}-0.59^{* * *} \\
(0.21)\end{array}$ & \\
\hline Rule of law index & & & & & $\begin{array}{r}-9.10^{* * *} \\
(1.48)\end{array}$ \\
\hline $\begin{array}{l}\text { Rule of law index } \times \text { Minwage } \\
\text { to GDP ratio }\end{array}$ & & & & & $\begin{array}{l}0.10^{* * *} \\
(0.03)\end{array}$ \\
\hline East Asia and the Pacific & $\begin{array}{r}-4.77^{* * *} \\
(1.32)\end{array}$ & $\begin{array}{r}-4.78^{* * *} \\
(1.32)\end{array}$ & $\begin{array}{r}-5.50^{* * *} \\
(1.43)\end{array}$ & $\begin{array}{r}-13.49 * * * \\
(4.36)\end{array}$ & $\begin{array}{r}-3.58^{* *} \\
(1.39)\end{array}$ \\
\hline Europe and Central Asia & $\begin{array}{r}-13.02^{* * *} \\
(1.03)\end{array}$ & $\begin{array}{r}-13.00^{* * *} \\
(1.04)\end{array}$ & $\begin{array}{r}-13.67^{* * *} \\
(1.14)\end{array}$ & $\begin{array}{r}-14.09^{* * *} \\
(2.81)\end{array}$ & $\begin{array}{r}-13.26^{* * *} \\
(1.07)\end{array}$ \\
\hline Latin America and the Caribbean & - & - & - & - & - \\
\hline Middle East and North Africa & $\begin{array}{r}-14.33^{* * *} \\
(1.23)\end{array}$ & $\begin{array}{r}-14.48^{* * *} \\
(1.43)\end{array}$ & $\begin{array}{r}-14.90^{* * *} \\
(1.31)\end{array}$ & $\begin{array}{r}2.88 \\
(7.39)\end{array}$ & $\begin{array}{r}-12.61^{* * *} \\
(1.39)\end{array}$ \\
\hline South Asia & $\begin{array}{l}-2.37 \\
(1.70)\end{array}$ & $\begin{array}{l}-2.35 \\
(1.71)\end{array}$ & $\begin{array}{l}-2.57 \\
(1.71)\end{array}$ & - & $\begin{array}{r}0.98 \\
(1.86)\end{array}$ \\
\hline Sub-Saharan Africa & $\begin{array}{r}-6.86^{* * *} \\
(1.59)\end{array}$ & $\begin{array}{r}-6.85^{* * *} \\
(1.60)\end{array}$ & $\begin{array}{r}-7.92^{* * *} \\
(1.78)\end{array}$ & $\begin{array}{l}-6.59 \\
(4.73)\end{array}$ & $\begin{array}{r}-4.05^{* *} \\
(1.77)\end{array}$ \\
\hline Constant & $\begin{array}{r}49.05^{* * *} \\
(6.28)\end{array}$ & $\begin{array}{r}49.12^{* * *} \\
(6.30)\end{array}$ & $\begin{array}{r}48.04^{* * *} \\
(6.32)\end{array}$ & $\begin{array}{r}-19.38 \\
(28.91)\end{array}$ & $\begin{array}{r}34.38^{* * *} \\
(7.12)\end{array}$ \\
\hline Year dummies & Yes & Yes & Yes & Yes & Yes \\
\hline Observations & 489 & 489 & 489 & 68 & 445 \\
\hline R-squared & 0.88 & 0.88 & 0.88 & 0.79 & 0.89 \\
\hline Number of countries & 47 & 47 & 47 & 20 & 45 \\
\hline
\end{tabular}

GDP = gross domestic product, USD = United States dollar.

Notes: Standard errors in parentheses; ${ }^{* * *} p<001,{ }^{* *} p<0.05,{ }^{*} p<0$.

Source: Authors' estimates based on CBRLRI database (accessed 5 January 2016); ILO KILM.

http://www.ilo.org/ilostat/faces/wcnav_defaultSelection?_afrLoop=246699509158316\&_afrWindowMode=0\&_afrWindowld=null\#!\%40\%

40\%3F_afrWindowld\%3Dnull\%26_afrLoop\%3D246699509158316\%26_afrWindowMode\%3D0\%26_adf.ctrl-state\%3Dg2madkays_45 (accessed 5 March 2016); World Development Indicators databases. https://data.worldbank.org/data-catalog/world-developmentindicators (accessed 1 June 2016); and World Governance Indicators. http://info.worldbank.org/governance/wgi/\#home (accessed 1 June 2016). 
While we do not get a statistically significant association between severance pay and informal employment, it is worth reiterating that the results are significantly different from that for dismissal regulations, which was one of the key points of the theoretical model. While the theoretical model showed that severance payments can promote structural transformation by providing insurance to risk-averse workers, it also showed that there exists an optimal level of severance payments and a severance payment more generous than this level would impede structural transformation. No such ambiguity exists regarding dismissal regulations and therefore the empirical results are broadly consistent with the theoretical model.

As for minimum wages, the results reported in Table 4 are similar to those for dismissal regulations. Countries with higher minimum wages relative to aggregate income levels as captured by GDP per capita tend to have higher shares of informal employment. Moreover, this association remains even when we include our various controls. The only exception is when we work with the inspection rate as a control for the enforcement regime. Switching from the inspection rate to the rule of law index as our control for the enforcement regime, however, yields qualitatively very similar results to Table 2: relatively high minimum wages in countries with strong rule of law seem to add to informality.

Overall, these results, though suggestive, do match up broadly with the theoretical predictions of this paper's model of the process of structural transformation in developing countries.

\section{CONCLUDING REMARKS}

Determining what types of labor market regulations are optimal for developing countries is challenging. In this paper, we constructed a theoretical model to get a better understanding of the issues involved. Our results suggest that getting rid of regulations that protect jobs and not workers is a good idea. Creating administrative hurdles for firms seeking to dismiss or layoff workers - such as through India's Industrial Disputes Act 1947 (see Anant et al. 2006 for details) -is a prime example of a policy protecting jobs and not workers. It is shown that mandated severance payments or unemployment insurance funded by a layoff tax can provide social protection and promote structural transformation by increasing the fraction of workers employed in the more productive formal sector and reducing informality. While in principle it is a good idea for the state to provide social protection to workers, whether it can actually execute such policies depends on state capacity. Empirically we find that labor market regulations that make it more difficult to fire workers increase informality while regulations that mandate severance payments to workers do not. Binding minimum wages also increase informality. 


\section{APPENDIX}

\section{A. Key Equations}

The key equations derived in the text are as follows under the assumption of uniform distribution for $\lambda$.

The aggregate labor market condition, (22) is given by

$$
\frac{\gamma}{2(1-\gamma)}\left(B w_{i}^{\frac{1}{\gamma-1}} \varphi^{*^{2}}+A\left(\frac{1-\lambda_{c}^{2}}{2}\right)^{\frac{\gamma}{1-\gamma}}\left(w_{f}\left(1-\lambda_{c}\right)\right)^{\frac{1}{\gamma-1}}\left(1-\varphi^{*^{2}}\right)\right)=\bar{L}
$$

The informal sector output is

$$
Z^{\prime}=B^{\prime} \int_{0}^{\varphi^{*}} \varphi^{1-\gamma} L_{i}(\varphi)^{\gamma} d G(\varphi)=\frac{B}{1-\gamma} w_{i}^{\frac{\gamma}{\gamma-1}} \int_{0}^{\varphi^{*}} \varphi d G(\phi)=\frac{B}{2(1-\gamma)} \varphi^{* 2} w_{i}^{\frac{\gamma}{\gamma-1}}
$$

while the formal sector output is

$$
Z^{F}=A^{\prime}\left(\frac{1-\lambda_{c}^{2}}{2}\right)^{\gamma} \int \varphi^{1-\gamma} L_{f}(\varphi)^{\gamma} d G(\varphi)=\frac{A}{2(1-\gamma)}\left(\frac{1-\lambda_{c}^{2}}{2}\right)^{\frac{\gamma}{1-\gamma}}\left(w_{f}\left(1-\lambda_{c}\right)\right)^{\frac{\gamma}{\gamma-1}}\left(1-\varphi^{* 2}\right)
$$

The aggregate net output can be written as

$$
Y=\frac{w_{i} L^{l}}{\gamma}+\frac{W_{f}\left(1-\lambda_{c}\right) L^{F}}{\gamma}+\lambda_{c} L^{F} z-\left(1-\varphi^{*}\right) F
$$

\section{B. Planner's Problem}

The planner's objective function is as follows:

$$
\operatorname{Max}_{\lambda_{c}(\varphi), L_{f}(\varphi), L_{i}(\varphi), \varphi^{*}}\left\{\begin{array}{c}
B^{\prime} \int_{\underline{\varphi}}^{\varphi^{*}} \varphi^{1-\gamma} L_{i}(\varphi)^{\gamma} d G(\varphi)+A^{\prime} \int_{\varphi^{*}}^{\bar{\varphi}}\left(\frac{1-\lambda_{c}(\varphi)^{2}}{2}\right)^{\gamma} \varphi^{1-\gamma} L_{f}(\varphi)^{\gamma} d G(\varphi) \\
+z \int_{\varphi^{*}}^{\bar{\varphi}} \lambda_{c}(\varphi) L_{f}(\varphi) d G(\varphi)-\left(1-G\left(\varphi^{*}\right)\right) F+\mu\left(\bar{L}-L^{\prime}-L^{F}\right)
\end{array}\right\}
$$

The first-order conditions are as follows:

$$
\begin{gathered}
L_{i}(\varphi): \gamma B^{\prime} \varphi^{1-\gamma} L_{i}(\varphi)^{\gamma-1}-\mu=0 \\
L_{f}(\varphi): \gamma A^{\prime}\left(\frac{1-\left(\lambda_{c}(\varphi)\right)^{2}}{2}\right)^{\gamma} \varphi^{1-\gamma} L_{f}(\varphi)^{\gamma-1}-\mu+\lambda_{c}(\varphi) z=0
\end{gathered}
$$


34 | Appendix

$$
\begin{gathered}
\lambda_{c}(\varphi): \gamma A^{\prime} \lambda_{c}(\varphi)\left(\frac{1-\left(\lambda_{c}(\varphi)\right)^{2}}{2}\right)^{\gamma-1} \varphi^{1-\gamma} L_{f}(\varphi)^{\gamma-1}-z=0 \\
\varphi^{*}: B^{\prime} \varphi^{* 1-\gamma} L_{i}\left(\varphi^{*}\right)^{\gamma} g\left(\varphi^{*}\right)-A^{\prime}\left(\frac{1-\lambda_{c}^{2}}{2}\right)^{\gamma} \varphi^{* 1-\gamma} L_{f}\left(\varphi^{*}\right)^{\gamma} g\left(\varphi^{*}\right)- \\
\lambda_{c} z L_{f}\left(\varphi^{*}\right)+g\left(\varphi^{*}\right) F+\mu\left(L_{f}\left(\varphi^{*}\right)-L_{i}\left(\varphi^{*}\right)\right) g\left(\varphi^{*}\right)=0
\end{gathered}
$$

Dividing (33) by (34) obtain

$$
\frac{\lambda_{c}(\varphi)}{\left(\frac{1-\left(\lambda_{c}(\varphi)\right)^{2}}{2}\right)}=\frac{z}{\mu-\lambda_{c}(\varphi) z}
$$

From the above note that $\lambda_{c}(\varphi)$ doesn't depend on $\varphi$. Next, (35) can be rewritten as

$$
B^{\prime} \varphi^{* 1-\gamma} L_{i}\left(\varphi^{*}\right)^{\gamma}-A^{\prime}\left(\frac{1-\lambda_{c}^{2}}{2}\right)^{\gamma} \varphi^{* 1-\gamma} L_{f}\left(\varphi^{*}\right)^{\gamma}-\lambda_{c} z L_{f}\left(\varphi^{*}\right)+F+\mu\left(L_{f}\left(\varphi^{*}\right)-L_{i}\left(\varphi^{*}\right)\right)=0
$$

\section{Decentralized Solution in the Risk-Neutral Case}

The equations for the decentralized equilibrium in the risk-neutral case are easily obtained from the ones derived in the text by setting $U(x)=x$. We gather the key first-order conditions in the decentralized case below.

$$
\begin{gathered}
L_{i}(\varphi): \gamma B^{\prime} \varphi^{1-\gamma} L_{i}(\varphi)^{\gamma-1}-w_{i}=0 \\
L_{f}(\varphi): \gamma A^{\prime}\left(\frac{1-\left(\lambda_{c}(\varphi)\right)^{2}}{2}\right)^{\gamma} \varphi^{1-\gamma} L_{f}(\varphi)^{\gamma-1}-w_{f}\left(1-\lambda_{c}\right)=0 \\
\lambda_{c}: \gamma A^{\prime} \lambda_{c}\left(\frac{1-\lambda_{c}^{2}}{2}\right)^{\gamma-1} \varphi^{1-\gamma} L_{f}(\varphi)^{\gamma-1}-z=0
\end{gathered}
$$

In addition, the no arbitrage condition for workers is

$$
\left(1-\lambda_{c}\right) w_{f}+\lambda_{c} z=w_{i}
$$


Using (42) rewrite (40) as

$$
A^{\prime} \varphi^{1-\gamma} \gamma\left(\frac{1-\lambda_{c}^{2}}{2}\right)^{\gamma} L_{f}(\varphi)^{\gamma-1}=w_{i}-\lambda_{c} z
$$

The condition for $\varphi^{*}$ in the decentralized case is given by

$$
B^{\prime} \varphi^{* 1-\gamma} L_{i}\left(\varphi^{*}\right)^{\gamma}-w_{i} L_{i}\left(\varphi^{*}\right)=A^{\prime}\left(\frac{1-\lambda_{c}^{2}}{2}\right)^{\gamma} \varphi^{* 1-\gamma} L_{f}\left(\varphi^{*}\right)^{\gamma}-w_{f}\left(1-\lambda_{c}\right) L_{f}\left(\varphi^{*}\right)-F
$$

Using (42) rewrite above as

$$
B^{\prime} \varphi^{* 1-\gamma} L_{i}\left(\varphi^{*}\right)^{\gamma}-A^{\prime}\left(\frac{1-\lambda_{c}^{2}}{2}\right)^{\gamma} \varphi^{* 1-\gamma} L_{f}\left(\varphi^{*}\right)^{\gamma}+w_{i}\left(L_{f}\left(\varphi^{*}\right)-L_{i}\left(\varphi^{*}\right)\right)-\lambda_{c} z L_{f}\left(\varphi^{*}\right)+F=0
$$

A comparison of the conditions above with the planner's problem shows that they are identical if $\mu=w_{i}$.

Note that $L_{f}(\varphi)$ is the same function of $\lambda_{c}, z$, and $\varphi$ in both cases. $L_{i}(\varphi)$ is same in both cases if $\mu=w_{i}$. Therefore, the two equations determining $\lambda_{c}$ and $\varphi^{*}$ become identical in the two cases, and hence, they give the same solution which in turn implies $\mu=w_{i}$.

Therefore, if the system of equations has a unique solution, then clearly the planner's problem corresponds to the decentralized equilibrium when workers are risk neutral.

\section{Severance Payments by Firms (voluntary and mandatory)}

Below we show that voluntary severance payments allow production efficiency. Denoting severance payments by $s$, the firms do the following maximization exercise.

$$
\begin{aligned}
& \operatorname{Max}_{L_{f}, w_{f}, \lambda_{c}, s}\left\{A^{\prime} \varphi^{1-\gamma}\left(\frac{1-\lambda_{c}^{2}}{2}\right)^{\gamma} L_{f}(\varphi)^{\gamma}-w_{f}\left(1-\lambda_{c}\right) L_{f}(\varphi)-\lambda_{c} L_{f}(\varphi) s\right\} \\
& \text { s.t. }\left(1-\lambda_{c}\right) U\left(w_{f}\right)+\lambda_{c} U(s+z) \geq U\left(w_{i}\right)
\end{aligned}
$$

The first-order conditions are

$$
\begin{gathered}
L_{f}(\varphi): A^{\prime} \varphi^{1-\gamma} \gamma\left(\frac{1-\lambda_{c}^{2}}{2}\right)^{\gamma} L_{f}(\varphi)^{\gamma-1}=w_{f}\left(1-\lambda_{c}\right)+\lambda_{c} s \\
w_{f}:-\left(1-\lambda_{c}\right) L_{f}(\varphi)+\rho\left(1-\lambda_{c}\right) U^{\prime}\left(w_{f}\right)=0
\end{gathered}
$$




$$
\begin{gathered}
s:-\lambda_{c} L_{f}+\rho \lambda_{c} U^{\prime}(s+z)=0 \\
\lambda_{c}:-A^{\prime} \varphi^{1-\gamma} \gamma \lambda_{c}\left(\frac{1-\lambda_{c}^{2}}{2}\right)^{\gamma-1} L_{f}(\varphi)^{\gamma}=\rho U\left(\left(w_{f}\right)-U(s+z)\right)-w_{f} L_{f}(\varphi)+L_{f}(\varphi) s
\end{gathered}
$$

From (47) and (48) verify that $U^{\prime}\left(w_{f}\right)=U^{\prime}(s+z)$, and hence, $w_{f}=s+z$. Therefore, (46) and (49) can be written as

$$
\begin{gathered}
A^{\prime} \varphi^{1-\gamma} \gamma\left(\frac{1-\lambda_{c}^{2}}{2}\right)^{\gamma} L_{f}(\varphi)^{\gamma-1}=w_{f}-\lambda_{c} z \\
A^{\prime} \varphi^{1-\gamma} \gamma \lambda_{c}\left(\frac{1-\lambda_{c}^{2}}{2}\right)^{\gamma-1} L_{f}(\varphi)^{\gamma-1}=w_{f}-s=z
\end{gathered}
$$

Verify that the above are the same as (41) and (43) in the case of risk-neutral workers (because $w_{f}=s+z$ implies $w_{i}=w_{f}$ ). Therefore, production efficiency is achieved if firms can offer severance payments voluntarily.

The case of government mandated severance payments is similar to the one discussed above. In this case, firms in the formal sector take $s$ as given and choose $L_{f}, w_{f}$, and $\lambda_{c}$. If the government wants to attain production efficiency it can choose $s$ such that $w_{f}(s)=s+z$ where $w_{f}(s)$ is the formal sector wage as a function of mandated severance payments $s$ chosen by the government.

Note from (46) that the amount of labor employed by a formal sector firm is given by

$$
L_{f}(\varphi)=\frac{\gamma}{1-\gamma} A \varphi\left(\frac{1-\lambda_{c}^{2}}{2}\right)^{\frac{\gamma}{1-\gamma}}\left(w_{f}\left(1-\lambda_{c}\right)+\lambda_{c} s\right)^{\frac{1}{\gamma-1}}
$$

The profit of a formal sector firm is given by

$$
\pi_{f}(\varphi)=\varphi A\left(\frac{1-\lambda_{c}^{2}}{2\left(w_{f}\left(1-\lambda_{c}\right)+\lambda_{c} s\right)}\right)^{\frac{\gamma}{1-\gamma}}
$$

Therefore, the aggregate labor market condition in this case is given by

$$
\frac{\gamma}{2(1-\gamma)}\left(B w_{i}^{\frac{1}{\gamma-1}} \varphi^{*^{2}}+A\left(\frac{1-\lambda_{c}^{2}}{2}\right)^{\frac{\gamma}{1-\gamma}}\left(w_{f}\left(1-\lambda_{c}\right)+\lambda_{c} s\right)^{\frac{1}{\gamma-1}}\left(1-\varphi^{*^{2}}\right)\right)=\bar{L}
$$


The indifference condition of entrepreneurs is given by

$$
\varphi^{*}\left(A\left(\frac{1-\lambda_{c}^{2}}{2\left(w_{f}\left(1-\lambda_{c}\right)+\lambda_{c} s\right)}\right)^{\frac{\gamma}{1-\gamma}}-B w_{i}^{\frac{\gamma}{\gamma-1}}\right)=F
$$

The informal sector output is same as in (29) above but the formal sector output is given by

$$
Z^{F}=A^{\prime}\left(\frac{1-\lambda_{c}^{2}}{2}\right)^{\gamma} \int \varphi^{1-\gamma} L_{f}(\varphi)^{\gamma} d G(\varphi)=\frac{A}{2(1-\gamma)}\left(\frac{1-\lambda_{c}^{2}}{2}\right)^{\frac{\gamma}{1-\gamma}}\left(w_{f}\left(1-\lambda_{c}\right)+\lambda_{c} s\right)^{\frac{\gamma}{\gamma-1}}\left(1-\varphi^{* 2}\right)
$$

And the aggregate output is given by

$$
Y=\frac{W_{i} L^{l}}{\gamma}+\frac{W_{f}\left(1-\lambda_{c}\right)+\lambda_{c} s}{\gamma} L^{F}+\lambda_{c} L^{F} z-\left(1-\varphi^{*}\right) F
$$

\section{Severance Payments with Leakage}

The first-order conditions for the case of voluntary severance payments with leakage are given by

$$
\begin{gathered}
L_{f}: A^{\prime} \varphi^{1-\gamma} \gamma\left(\frac{1-\lambda_{c}^{2}}{2}\right)^{\gamma} L_{f}^{\gamma-1}=w_{f}\left(1-\lambda_{c}\right)+\lambda_{c} s \\
w_{f}:-\left(1-\lambda_{c}\right) L_{f}+\rho\left(1-\lambda_{c}\right) U^{\prime}\left(w_{f}\right)=0 \\
s:-\lambda_{c} L_{f}+\rho \phi \lambda_{c} U^{\prime}(\phi s+z)=0 \\
\lambda_{c}:-A^{\prime} \varphi^{1-\gamma} \gamma \lambda_{c}\left(\frac{1-\lambda_{c}^{2}}{2}\right)^{\gamma-1} L_{f}^{\gamma}=\rho\left(U\left(w_{f}\right)-U(\phi s+z)\right)-w L_{f}+L_{f} s
\end{gathered}
$$

(59) and (61) above imply that

$$
\rho=\frac{L_{f}}{\phi U^{\prime}(\phi s+z)}=\frac{L_{f}}{U^{\prime}\left(w_{f}\right)}
$$

Therefore,

$$
\phi U^{\prime}(\phi s+z)=U^{\prime}\left(w_{f}\right)
$$

Note from above that since $\phi<1, U^{\prime}\left(w_{f}\right)<U^{\prime}(\phi s+z)$ or $w_{f}>\phi s+z$. That is, firms do not provide full insurance in this case. 
Therefore, (61) is given by

$$
A^{\prime} \varphi^{1-\gamma} \gamma \lambda_{c}\left(\frac{1-\lambda_{c}^{2}}{2}\right)^{\gamma-1} L_{f}^{\gamma-1}=\frac{U(\phi s+z))-U(w)}{U^{\prime}\left(w_{f}\right)}+w_{f}-s
$$

And (58) is given by

$$
A^{\prime} \varphi^{1-\gamma} \gamma\left(\frac{1-\lambda_{c}^{2}}{2}\right)^{\gamma} L_{f}^{\gamma-1}=w_{f}\left(1-\lambda_{c}\right)+\lambda_{c} s
$$

(64) and (65) do not correspond to (50) and (51). Therefore, production efficiency cannot be attained by voluntary severance payments or mandated severance payments corresponding to the level that firms would offer voluntarily if credibility was not an issue.

If the government mandates severance payments or collects a layoff tax to provide unemployment insurance to workers (albeit with leakage), then firms take $s$ as given. In this case, equations (64) and (65) still hold, but (63) does not hold.

The key equations for the numerical simulation are as follows. From (64) and (65) obtain

$$
\left(\frac{1-\lambda_{c}^{2}}{2 \lambda_{c}}\right)=\frac{w\left(1-\lambda_{c}\right)+\lambda_{c} s}{\frac{U(\phi s+z))-U((w)}{\phi U^{\prime}(\phi s+z)}+w-s}
$$

The indifference condition for workers is given by

$$
\left(1-\lambda_{c}\right) U\left(w_{f}\right)+\lambda_{c} U(\phi s+z)=U\left(w_{i}\right)
$$

The aggregate labor market condition, the indifference condition for entrepreneurs, and expression for output are same as in the case without leakage and are given by (54), (55), and (57), respectively.

\section{E. Administrative Burden of Firing}

If the government imposes a firing tax of $b$, the first-order conditions in the formal sector are given by

$$
\begin{aligned}
& \operatorname{Max}_{L_{f}, w_{f}, \lambda_{c}}\left\{A^{\prime} \varphi^{1-\gamma}\left(\frac{1-\lambda_{c}^{2}}{2}\right)^{\gamma} L_{f}(\varphi)^{\gamma}-w_{f}\left(1-\lambda_{c}\right) L_{f}(\varphi)-\lambda_{c} L_{f}(\varphi) b\right\} \\
& \text { s.t. }\left(1-\lambda_{c}\right) U\left(w_{f}\right)+\lambda_{c} U(z) \geq U\left(w_{i}\right)
\end{aligned}
$$

The first-order conditions are

$$
L_{f}(\varphi): A^{\prime} \varphi^{1-\gamma} \gamma\left(\frac{1-\lambda_{c}^{2}}{2}\right)^{\gamma} L_{f}(\varphi)^{\gamma-1}=w_{f}\left(1-\lambda_{c}\right)+\lambda_{c} b
$$




$$
\begin{gathered}
w_{f}:-\left(1-\lambda_{c}\right) L_{f}(\varphi)+\rho\left(1-\lambda_{c}\right) U^{\prime}\left(w_{f}\right)=0 \\
\lambda_{c}:-A^{\prime} \varphi^{1-\gamma} \gamma \lambda_{c}\left(\frac{1-\lambda_{c}^{2}}{2}\right)^{\gamma-1} L_{f}(\varphi)^{\gamma}=\rho\left(U\left(w_{f}\right)-U(z)\right)-w L_{f}(\varphi)+L_{f}(\varphi) b
\end{gathered}
$$

Using (69), (70) can be written as

$$
A^{\prime} \varphi^{1-\gamma} \gamma \lambda_{c}\left(\frac{1-\lambda_{c}^{2}}{2}\right)^{\gamma-1} L_{f}(\varphi)^{\gamma-1}=w_{f}-\psi-b
$$

where $\psi$ in this case is given by $\frac{U\left(w_{f}\right)-U(z)}{U^{\prime}\left(w_{f}\right)}$.

Next, (68) and (71) give us the key equation

$$
\frac{w_{f}\left(1-\lambda_{c}\right)+\lambda_{c} b}{w_{f}-\psi-b}=\left(\frac{1-\lambda_{c}^{2}}{2 \lambda_{c}}\right)
$$

Again, (72) and $\left(1-\lambda_{c}\right) U\left(w_{f}\right)+\lambda_{c} U(z)=U\left(w_{i}\right)$ determine $w_{f}$ and $\lambda_{c}$ independent of $\varphi$.

It is clear from the discussion in the section on severance payments that to restore efficiency using $b$ we need the following two conditions to be satisfied.

$$
\begin{aligned}
& A^{\prime} \varphi^{1-\gamma} \gamma\left(\frac{1-\lambda_{c}^{2}}{2}\right)^{\gamma} L_{f}(\varphi)^{\gamma-1}=w_{i}-\lambda_{c} z \\
& A^{\prime} \varphi^{1-\gamma} \gamma \lambda_{c}\left(\frac{1-\lambda_{c}^{2}}{2}\right)^{\gamma-1} L_{f}(\varphi)^{\gamma-1}=z
\end{aligned}
$$

It follows from (68) and (71) that we need $w_{f}\left(1-\lambda_{c}\right)+\lambda_{c} b=w_{i}-\lambda_{c} z$ and $w_{f}-\psi-b=z$. Suppose the policy maker chooses $b$ such that $w_{f}-\psi-b=z$. This implies $-b=\psi-\left(w_{f}-z\right)>0$. The last inequality follows from the concavity of the utility function. Therefore, a firing subsidy can be chosen to satisfy (74). At that level of $b$ we also need $w_{f}\left(1-\lambda_{c}\right)+\lambda_{c} b=w_{i}-\lambda_{c} z$. Verify that $w_{f}\left(1-\lambda_{c}\right)+\lambda_{c} b$ equals $w_{f}-\lambda_{c} \psi-\lambda_{c} z$. Therefore, we need $w_{f}-\lambda_{c} \psi$ to equal $w_{i}$. Or, we need $w_{f}-w_{i}=\lambda_{c} \psi$. But note that $\lambda_{c} \psi$ equals $\frac{U\left(w_{f}\right)-U\left(w_{i}\right)}{U^{\prime}\left(w_{f}\right)}$ which is strictly greater than $w_{f}-w_{i}$ from the concavity of $U$. Therefore, efficiency cannot be restored using a firing subsidy.

For numerical simulation, the aggregate labor market condition, the indifference condition, and the expression for aggregate output are obtained simply by replacing $s$ by $b$ in equations (54), (55), and (57). 


\section{REFERENCES}

Abidoye, Babatunde, Peter Orazem, and Milan Vodopivec. 2014. "Mandatory Costs by Firm Size Thresholds: Firm Location, Growth and Death in Sri Lanka." IZA Journal of Labor \& Development 3: 36.

Adams, Zoe, Louise Bishop, and Simon Deakin. 2015. The CBR-LRI Dataset: Version of December 2015 (117 Countries). Report for the Asian Development Bank. Centre for Business Research, University of Cambridge (see also, Armour, J., Deakin, S., \& Siems, M. CBR Leximetric Datasets [Dataset]. https://doi.org/10.17863/CAM.506).

Albrecht, James, Lucas Navarro, and Susan Vroman. 2009. "The Effects of Labor Market Policies in an Economy with an Informal Sector.” Economic Journal 119 (539): 1105-29.

Anant, TCA, Rana Hasan, P. Mohapatra, R. Nagaraj, and S. K. Sasikumar. 2006. "Labor Markets in India: Issues and Perspectives." In Labor Markets in Asia: Issues and Perspectives edited by Jesus Felipe and Rana Hasan. United Kingdom: Palgrave Macmillan.

Blanchard, Olivier J., and Jean Tirole. 2008. "The Joint Design of Unemployment Insurance and Employment Protection: A First Pass." Journal of the European Economic Association 6 (1): 45-77.

Bosch, Mariano, and Julen Esteban-Pretel. 2012. "Job Creation and Job Destruction in the Presence of Informal Markets.” Journal of Development Economics 98 (2): 270-86.

Botero, Juan, Simeon Djankov, Rafael La Porta, Florencio Lopez-de-Silanes, Andrei Shleifer. 2004. "The Regulation of Labor." Quarterly Journal of Economics 119 (3): 1339-82.

Chatterjee, Urmila, and Ravi Kanbur. 2014. "Regulation and Non-Compliance: Magnitudes and Patterns for India's Factories Act." Mimeo.

de Paula, Áureo, and José A. Scheinkman. 2007. "The Informal Sector." NBER Working Paper No. 13486.

Djankov, Simeon, Tim Ganser, Caralee McLiesh, Rita Ramalho, Andrei Shleifer. 2008. "The Effect of Corporate Taxes on Investment and Entrepreneurship.” NBER Working Paper No. 13756.

Djankov, Simeon, and Rita Ramalho. 2009. “Employment Laws in Developing Countries.” Journal of Comparative Economics 37 (1): 3-13.

Fugazza, Marco, and Jean-François Jacques. 2004. "Labor Market Institutions, Taxation and the Underground Economy.” Journal of Public Economics 88 (1-2): 395-418.

Ghani, Ejaz, William R. Kerr, and Stephen D. O'Connell. 2013. "The Exceptional Persistence of India's Unorganized Sector.” World Bank Policy Research Working Paper No. 6454.

Kanbur, Ravi. 2017. “Informality: Causes, Consequences and Policy Responses.” Review of Development Economics 21 (4): 939-61. 
Meghir, Costas, Renata Narita, and Jean-Marc Robin. 2015. "Wages and Informality in Developing Countries." American Economic Review 105 (4):1509-46.

Summers, Lawrence H. 1989. "Some Simple Economics of Mandated Benefits." The American Economic Review 79 (2): 177-83.

Zenou, Yves. 2008. "Job Search and Mobility in Developing Countries: Theory and Policy Implications." Journal of Development Economics 86 (2): 336-55. 


\section{Labor Market Regulations in the Context of Structural Transformation}

Determining what types of labor market regulations are optimal is challenging. Governments in developing countries attempt to regulate labor markets through wages, hours of work, hiring and firing restrictions, and work conditions. This paper constructs a theoretical model to study labor market regulations within the context of structural transformation. When workers are risk averse and the market for insurance against labor income risk is missing, regulations that provide insurance to workers are enhancing and raise the fraction of workers employed in the more productive formal sector. However, regulations that create barriers to the dismissal of workers may impede the transition to formal sector employment and reduce workers' welfare. Empirically, the paper finds that dismissal regulations increase the share of informal employment; however, severance payments to workers do not.

\section{About the Asian Development Bank}

ADB's vision is an Asia and Pacific region free of poverty. Its mission is to help its developing member countries reduce poverty and improve the quality of life of their people. Despite the region's many successes, it remains home to a large share of the world's poor. ADB is committed to reducing poverty through inclusive economic growth, environmentally sustainable growth, and regional integration.

Based in Manila, ADB is owned by 67 members, including 48 from the region. Its main instruments for helping its developing member countries are policy dialogue, loans, equity investments, guarantees, grants, and technical assistance. 